MISS SOPHIE HAGE (Orcid ID : 0000-0003-0010-4208)

MRS. AURELIA HUBERT-FERRARI (Orcid ID : 0000-0001-6381-1415)

Article type : Original Manuscript

\title{
Flow dynamics at the origin of thin clayey sand lacustrine turbidites: Examples from Lake Hazar, Turkey
}

Sophie Hage ${ }^{1,2}$, Aurélia Hubert-Ferrari ${ }^{1}$, Laura Lamair ${ }^{1}$, Ulaş Avşar ${ }^{3}$, Meriam El Ouahabi ${ }^{4,5}$, Maarten Van Daele ${ }^{6}$, Frédéric Boulvain ${ }^{5}$, Mohamed Ali Bahri ${ }^{7}$, Alain Seret ${ }^{7}$, Alain Plenevaux ${ }^{7}$

1. University of Liège, Department of Geography, Liège, Belgium.; sophie.hage@ soton.ac.uk; aurelia.ferrari@ulg.ac.be

2. University of Southampton, School of Ocean and Earth Sciences, U.K.

3. King Abdullah University of Science and Technology (KAUST), Thuwal, Saudi Arabia;

4. University of Cologne, Department of Geography, Germany;

5. University of Liège, Department of Geology, Liège, Belgium;

6. Ghent University, Renard Centre of Marine Geology, Department of Geology, Ghent, Belgium;

7. University of Liège, GIGA-Cyclotron Research Centre, Liège; Belgium;

Associate Editor - Jaco Baas

Short Title - Flow dynamics of thin clayey sand turbidites

\begin{abstract}
Turbidity currents and their deposits can be investigated using several methods, i.e. direct monitoring, physical and numerical modelling, sediment cores and outcrops. The present study focuses on thin clayey sand turbidites found in Lake Hazar (Turkey) occurring in eleven clusters of closely spaced This is an Accepted Article that has been peer-reviewed and approved for publication in the Sedimentology, but has yet to undergo copy-editing and proof correction. Please cite this article as an "Accepted Article"; doi: 10.1111/sed.12380 This article is protected by copyright. All rights reserved.
\end{abstract}


thin beds. Depositional processes and sources for three of those eleven clusters are studied at three coring sites. Bathymetrical data and seismic reflection profiles are used to understand the specific geomorphology of each site. X-ray, thin sections and CT-scans imagery combined with grain-size, geochemical and mineralogical measurements on the cores allow characterisation of the turbidites. Turbidites included in each cluster were produced by remobilization of surficial slope sediment, a process identified in very few studies worldwide. Three types of turbidites are distinguished and compared with deposits obtained in flume studies published in the literature. Type 1 is made of an ungraded clayey silt layer issued from a cohesive flow. Type 2 is composed of a partially graded clayey sand layer overlain by a mud cap, attributed to a transitional flow. Type 3 corresponds to a graded clayey sand layer overlain by a mud cap issued from a turbulence-dominated flow. While the published experimental studies show that turbulence is damped by cohesion for low clay content, type 3 deposits of this study show evidence for a turbulence dominated mechanism despite their high clay content. This divergence may in part relate to input variables such as water chemistry and clay mineralogy that are not routinely considered in experimental studies. Furthermore, the large sedimentological variety observed in the turbidites from one coring site to another is related to the evolution of a sediment flow within a field scale basin made of a complex physiography that cannot be tackled by flume experiments.

Keywords: Clayey sand turbidites, cohesion, shallow slope failure, subaqueous sediment density flows, turbulence

\section{INTRODUCTION}

\section{Understanding turbidity currents}

In the broad sense, turbidity currents correspond to subaqueous sediment-laden flows driven by the excess density of sediments relative to the surrounding water (Kuenen \& Migliorini, 1950; Talling et al., 2012). Such flows pose a potential geohazard to strategically important seafloor infrastructure (e.g. 
Carter et al., 2014), transport globally significant amounts of organic carbon (Galy et al., 2007), and their deposits may act as important hydrocarbon reservoirs (Nilsen et al., 2008). Despite their importance, both the dynamic processes at their origin and the formation of their resulting deposits, called turbidites, are still far from completely understood (Talling et al., 2012; 2013).

Depositional processes of turbidites have primarily been inferred indirectly based on ancient deposits in cores or outcrops, which represent only an in-time snapshot of a dynamic evolving flow (Sumner et al., 2009, Talling et al., 2012). Indeed, an idealised model based on flume experiments divides a turbidity current into three dynamic parts (Middleton, 1966, 1967, Middleton \& Hampton, 1973, Kneller \& Buckee, 2000). The head is the front of the flow and is characterised by resistance to the ambient water, leading to intense mixing. The body is the fastest part of the current and comprises two zones: the bottom zone at the interface with the floor and characterised by a higher density; and the upper zone more dilute and interacting with the ambient fluid. The tail corresponds to the third part, which is characterised by a decelerated regime and a low sediment concentration. Therefore, reconstruction of flow processes from the resulting deposits is challenging. In particular, many flows appear to become progressively more dilute as they dissipate downslope. Hence the resultant deposits in distal locations are often very different to those in proximal locations where distal deposits may represent only deposition from a dilute head. Furthermore, change of flow characteristics (for example, velocity, sediment concentration and grain size) can also occur after entrainment of substrate by sea floor erosion or by localised effect of topography and confinement (Parker, 1982).

A more complete understanding can be achieved by physical modelling in laboratories and direct field monitoring. However, the acquisition of field data is complicated (due to inaccessible locations, unpredictable occurrence and difficulty for instruments to monitor highly concentrated flows) and, by consequence, restricted (Talling et al., 2012; 2013). Laboratory experiments have thus been used to infer the relationships between flow characteristics and their deposits (e.g. Amy et al., 2006; Baas et al., 2011; Sumner et al., 2008, 2009; Manica, 2012). The main critical points are: (i) that all of the scaling relationships between models and reality cannot be held; and (i) 
that laboratories cannot achieve the full diversity of flows with respect to durations, concentrations, volumes, materials and velocities (Talling et al., 2015).

\section{Importance of clay within a turbidity current}

Flume experiments have shown that the presence of clay plays a crucial role in turbidity current dynamics (e.g. Amy et al., 2006; Baas et al., 2011; Sumner et al., 2009; Manica, 2012). In particular, small amounts of clay (as low as 5\%; Postma, 1986) brings cohesive strength to sediment mixtures and can damp turbulence.

If turbulence is suppressed, deceleration of the cohesive sediment flow can lead to en masse deposition, i.e. deposition of all the particles instantaneously, without any segregation. This results in a lack of grading in the deposit. Conversely, once decelerated, a turbulence-dominated flow will settle the particles incrementally, leading to segregation within the deposits and visible grading. Observation of the deposits may thus help reconstruct the properties of the flow.

\section{Lacustrine turbidites}

Sediment flows occur in both lacustrine and marine settings, but there are key differences in the environments. The first difference relates to the water chemistry where marine systems are saline and lakes contain fresh water. Secondly, sedimentation rates in lakes allow to retrieve a sedimentary record with a higher temporal resolution compared to deep marine systems (Cohen, 2003). Thirdly, the accessibility and relative scale of lacustrine settings permits much higher resolution studies as compared with marine sites.

Lacustrine turbidites have been studied extensively in many seismically active areas, because turbidity currents may be triggered by large-magnitude earthquakes and thus be used in palaeoseismology. For example, evidence of repeated subaqueous slope failures and turbidites in multiple Chilean and Argentinian lakes has been used to reconstruct large-magnitude earthquake recurrence and palaeointensities (Chapron et al., 2006; Moernaut et al. 2007, 2014 ; Bertrand et al., 2008; Waldmann et al., 2011; Van Daele et al., 2014a, 2015). Earthquake-triggered turbidites in the Marmara Sea and the 
Boraboy Lake have been used to infer palaeo-ruptures of the North Anatolian Fault threatening the city of Istanbul (McHugh et al., 2006; Avsar et al., 2015; Drab et al., 2015). Sedimentary archives in Swiss Alpine lakes have also helped to characterise the recurrence of strong earthquakes in a moderate seismicity region (Becker et al., 2002; Monecke et al., 2006; Strasser et al., 2006, 2013; Beck, 2009). However, care should be taken because lacustrine turbidites can also be triggered by other processes that can be added to or confused with earthquake triggering (for example, deltaic collapses, storms and floods).

\section{Aims}

The present paper focuses on the depositional processes of thin clayey sand turbidites interpreted to result from turbidity current activity found in Lake Hazar, a tectonic lake crossed by the EastAnatolian Fault (EAF) in Turkey (Fig.1). Thin clayey sand turbidites are herein defined as millimetre-thin layers composed of sandy particles mixed with a high proportion $(>30 \%)$ of clay relative to the total sediment volume, as classified by Shephard (1954). These layers are different from the hemipelagic background sedimentation of homogenous clayey silt and occur in clusters of two to eight thin beds. In the following, an event set will refer to a group of closely spaced thin turbidites separated by 1 to $2 \mathrm{~cm}$ of background sediments. Event sets occur within 10 to $20 \mathrm{~cm}$ of one another within vertically cored successions.

This study addresses the following questions.

1. What are the sources and triggers for turbidites found in Lake Hazar? Why are they organised into closely-spaced thin beds within event sets?

The first questions deal with the sediment sources and triggering mechanisms at the origin of the thin turbidites, which are distributed into clusters of event sets as defined above.

This article is protected by copyright. All rights reserved. 
2. How did the flows behave and how did their behaviour change in relation to the basin physiography?

Here the flow dynamics at the origin of thin clayey sand turbidites is addressed. Very few comprehensive field studies of this type of sedimentary event, i.e. both millimetre-thin and clay-rich with still a sandy content, are found in the literature (e.g. Bouma, 2000). The studied turbidites are compared between three cores located at a different distance from the sources and in different subbasins characterised by different surrounding physiography. In particular, this study seeks to test any flow behaviour changes from turbulent, transitional to laminar state.

\section{Do the deposits from Lake Hazar validate flume experiments?}

Several flume experiments have shown that mixtures of clay and sand strongly influenced turbidity current dynamics, low amounts of clay being able to damp turbulence (Postma, 1986). Four flume experiments found in the literature are here used to understand how clayey sand turbidites were deposited at Lake Hazar (Amy et al., 2006; Sumner et al., 2009; Baas et al., 2011; Manica, 2012). Comparison of the deposits from Lake Hazar with those generated in experimental studies provides a valuable test of scaled-down models. Then the wider application and limitations of existing experimental set ups are discussed.

\section{SETTINGS}

\section{Tectonic and geological setting}

Lake Hazar $\left(38.48^{\circ} \mathrm{N} ; 39.40^{\circ} \mathrm{E}\right)$ occupies a transtensional basin located along the central part of the East-Anatolian Fault (EAF) in Turkey (Fig.1). This major strike-slip fault is located at the boundary between the Arabian and Anatolian plates (Hempton et al., 1983; Hempton \& Dunne, 1984; Cetin et al., 2003) and already ruptured over most of its length in a series of earthquakes with a moment magnitude of 7 during the 19th Century (Ambraseys, 1989; Nalbant et al., 2002).

This article is protected by copyright. All rights reserved. 
Lake Hazar is crossed by several fault splays characterised by left-lateral motion and normal displacement along the eastern steep margins (Fig.1; Garcia Moreno et al., 2011). Most of the left-lateral motion is accommodated by the master fault which continues across the full length of the lake (Garcia Moreno et al., 2011). Normal faults are also located in the eastern, deeper part, resulting in a division of the lake in two sub-basins (Cetin et al., 2003; Garcia Moreno et al., 2011; Eriş, 2013): a deep basin (maximum depth of $216 \mathrm{~m}$ ) in the eastern half and a shallow basin (maximum depth of $c a 120 \mathrm{~m}$ ) in the western half (Fig. 1).

The geology of the Hazar catchment is diverse (Herece, 2008). In the western end of the lake, the Kürk catchment is mostly composed of the Palaeozoic and Mesozoic Puturge metamorphic complex to the south and of the Cenomanian Yüksekova Melange (gabbros, basalts, andesites and dacite dykes) to the north. The steep southern margin of Lake Hazar and the Hazar Mountains are mostly composed of terrains of the Eocene Maden Melange (volcanic and sedimentary formations), but Maastrichian limestone and clastics are locally present.

\section{Geomorphological, fluvial and limnological context}

Lake Hazar is $25 \mathrm{~km}$ long, $7 \mathrm{~km}$ wide and $216 \mathrm{~m}$ deep at its maximal extents (Garcia Moreno et al., 2011; Eriş, 2012). The steep southern slopes of the lake are bordered by the Hazar Mountains peaking at $2350 \mathrm{~m}$ whereas the northern margins are more gentle and surrounded by a lower relief.

A dense network of rivers and streams drains the Lake Hazar catchment area, most of them being ephemeral in response to the seasonal precipitations (Garcia Moreno et al., 2011; Eriş, 2012). The main Kürk River flows into the western extremity where it forms a large alluvial delta (Fig.1). Before 1957, the Kürk River provided the largest water inflow to the lake (Günek \& Yiğit, 1995; Şen \& Topkaya, 1997). Presently the Behrimaz River, an anthropic capture at the north-eastern end of the lake, provides most of the water inflow. The Kürk River and the adjacent river near the town of Sivrice provide the most important bedload to the lake (Şen \& Topkaya, 1997; Şen et al., 2007). Peak flows occur during spring linked to snow melt and precipitations (Günek \& Yiğit, 1995; Şen \& Topkaya, 1997).

This article is protected by copyright. All rights reserved. 
In historical times, several water level changes affected the lake (Tonbul \& Yiğit, 1995). From at least the 12th Century until the 18th Century a low lake level occurred as attested to by the continuous occupation of the Armenian settlement (Yiğit, 1995, Hubert-Ferrari et al., 2017). From the beginning of the 19th Century, a high lake level prevailed, which is attested by the drowning of an Armenian monastery located along the southern lake shore (see Promontory on Fig. 1; Tonbul \& Yiğit, 1995). After 1969, a 10 m anthropic lowstand occurred due to hydraulic water pumping (Tonbul \& Yiğit, 1995).

Limnological measurements have shown that the lake is an oligotrophic, hard-water, alkaline soda lake (pH around 9.3) with mixing in spring and autumn (Timm et al., 2013; Koçer and Sen, 2014). It is stratified from June to September with a thermocline between $10 \mathrm{~m}$ and $20 \mathrm{~m}$ of water depth. The salinity of Lake Hazar is $16 \%$ (Sen et al., 2002). The phytoplankton community comprises diatoms, Chlorophyta, Cyanophyta and Pyrrophyta (Koçer \& Sen, 2014). The identified fauna present at the lake bottom is composed of two main groups of invertebrates: Oligochaetes ( $c a$ 69\%) and Chironomid larvae (ca 19\%) (Timm et al. 2013). The intense biological sediment reworking within the upper centimetres has prevented any preservation of laminations.

\section{MATERIALS AND METHODS}

\section{Fieldwork}

Geophysical data and sediment cores were collected from the lake during the summers of 2006 and 2007. Three coring sites have been studied in the context of this research (Fig. 1).

Two sets of seismic reflection profiles were collected. The first one acquired a total of 44 seismic reflection profiles using a centipede multi-electrode sparker as acoustic source (dominant frequency of 400 to $1500 \mathrm{~Hz}$ ) and a 10 hydrophone single-channel streamer as receiver (with an active length of 2.7 m). An Innomar SES2000 compact sub-bottom profiler (Innomar Technologie GmbH, Rostock, Germany) was used to acquire the second set of seismic lines. The two seismic datasets covered the entire lake with a variable spacing, from $5 \mathrm{~m}$ apart on the lake margins and deltaic slopes to $250 \mathrm{~m}$ apart in the more homogeneous parts of the basin (see top left inset in Fig. 2). Side-scan sonar images 
were obtained using a KLEIN300 device (Klein Tools, Lincolnshire, IL, USA) recording simultaneously in two frequency bands of $100 \mathrm{kHz}$ and $500 \mathrm{kHz}$. The seismic and side-scan surveys allowed to understand the complex fault-system in the lake (Fig. 1; Garcia Moreno et al., 2011) and to map the sedimentary infill. The base of Holocene infill is constrained by a major unconformity clearly identifiable in all profiles (Garcia Moreno et al., 2011; Eriş, 2012).

A bathymetrical map was computed by kriging using the water depths imaged from contouring the first return from the two seismic datasets. The resolution of the bathymetrical map corresponds to the seismic datasets resolution, i.e. $c a 1 \mathrm{~m}$ of vertical resolution and $c a 5$ to $80 \mathrm{~m}$ of horizontal resolution for the western half part of the basin. The depth values obtained after kriging allowed to compute a map of the basin slopes (Fig. 2).

Sediment cores were taken using two different core sampling systems. Five metre long cores were collected with a piston hammering system while short cores with a length of $c a 1.2 \mathrm{~m}$ were acquired by a gravity corer (Uwitec model; Uwitec, Mondsee, Austria). In total seven cores collected from three study sites were used for this research, i.e. two long cores in sites 1 and 2 and five short cores in the three study sites (Figs 1, 4, 5 and 6). Both short and long cores were taken in sites 1 and 2, respectively, in order to compare replicates issued from the same location, and to evaluate potential coring artefacts.

\section{Laboratory analyses}

Background sediments in the cores are mostly composed of hemipelagic clayey silt with a low fine sand content. The cores also show thin clayey sand turbidites defined as millimetre-thin layers comprising coarser grains compared to the background sediments. The turbidites are separated by 1 to $2 \mathrm{~cm}$ of background sedimentation and they are arranged in clusters, forming different event sets of turbidites. Therefore in the following an event set refers to a cluster of two to eight closely spaced thin turbidites. Event sets are separated from one another by more than $10 \mathrm{~cm}$ of background sediments (Fig. 4).

This article is protected by copyright. All rights reserved. 
In total, eleven event sets of thin turbidites have been identified both visually and quantitatively in the long cores. This research focuses on three sets among the eleven event sets observed: event sets B, C and D (Fig. 4). The seven deepest sets were excluded because they are not covered by the short cores. The event set A near the top of the cores was also excluded for three reasons. Firstly, there were significant coring deformations. Secondly, strong anthropic imprints on the sedimentation occurred during the $20^{\text {th }}$ Century. Thirdly, the lake level increased by $30 \mathrm{~m}$ after the event set B, drastically changing the lake dynamics from the $18^{\text {th }}$ Century when the event set A occurred (HubertFerrari et al., 2017).

In order to investigate the three event sets in detail, a series of non-destructive and destructive analyses were performed. Artefacts potentially associated with core sampling have been carefully considered by comparing the sedimentary structures observed both in the long and short cores issued from the same sites. Furthermore, the three studied event sets are located far from the disturbed tops of the long piston cores.

\section{Non-destructive measurements}

Photographs and X-ray radiographs of the cores were acquired to identify the turbidites. Extraction of the X-ray greyscale profiles allowed an objective quantification. Black levels reflect high X-ray attenuation whereas white levels display low X-ray attenuation on Figs 5 and 6.

Magnetic susceptibility was measured at a $2 \mathrm{~mm}$ increment using a handheld Bartington MSE2 surface sensor (Bartington Instruments Limited, Witney, UK). Magnetic susceptibility reflects the magnetizability of a particle in the presence of a magnetic field and is generally used as a proxy indication for variables such as grain size and terrigenous content of lacustrine sediments (Last \& Smol, 2002). However, this physical property should be used together with other parameters for core correlation because it sometimes may under-represent the reality in the case of non-magnetic material. High resolution grain-size and geochemical measurements allowed the present study to rule out this uncertainty.

This article is protected by copyright. All rights reserved. 
Geochemical elements were gathered on each core at $2 \mathrm{~mm}$ down-core intervals using an Avaatech XRF Core Scanner with a $10 \mathrm{kV}$ incident beam (Avaatech, Alkmaar, The Netherlands; Jan Weltje \& Tjallingii, 2008). Ratios between some elements ( $\mathrm{Ca}, \mathrm{Ti}, \mathrm{Fe}$ and $\mathrm{Al}$ ) helped to investigate the provenance of sediment present in the three coring sites.

Five specific turbidites were investigated in more detail on the short cores using an X-ray Computed Tomography scanner eXplore 120 microCT (CT-scan; Gamma Medica, USA/GE Healthcare, UK). This system acquires high-resolution (i.e. $100 \mu \mathrm{m}$ ) images of samples that can be reconstructed to a three-dimensional volume (Bahri et al., 2010). The customized protocol 'Fastscan 360' was used for the acquisition $\left(70 \mathrm{kV}, 0.512 \mathrm{mAs}, 360\right.$ views over $360^{\circ}$, continuous rotation). The 3D reconstruction used the Feldkamp filtered back-projection algorithm with a cutoff at the Nyquist frequency and an isotropic voxel size of $100 \mu \mathrm{m}$ (Bahri et al., 2010). The resulting images allowed a detailed 3D visualisation of the deposits that would not have been achieved by any other imaging system, such as conventional medical X-ray CT scanners (e.g. Van Daele et al., 2014b). The grey levels obtained display the X-ray attenuation of the sediments, white being related to high X-ray attenuation and black to low X-ray attenuation, which depends mainly on their average atomic number and density (Migeon et al., 1998; Last \& Smol, 2002; Cnudde \& Boone, 2013).

\section{Destructive measurements}

Organic matter and carbonate content were acquired by 'loss on ignition' following the protocol of Heiri et al. (2001) at $1 \mathrm{~cm}$ of interval. In addition, Total Organic Carbon (TOC), Carbon/Nitrogen $(\mathrm{C} / \mathrm{N})$ ratios and carbon stable isotopes were measured after treatment with $\mathrm{HCl}$ to remove all of the carbonate minerals. For the organic geochemical measurements, both the turbidites and the background sediments (10 samples) in between were sampled at site 2 .

Bulk mineralogical composition of the sediments was measured with an X-ray Powder Diffractometer (Bruker D8-Advance; Bruker, Billerica, MA, USA). The turbidites and the background sediments in between (18 samples at site 1 and 21 samples at site 2 through the 
cores) were sampled. Mineralogy was used to assess the sediment sources of the turbidites and was compared to the background sediments. Given the Hazar geology, the onland sedimentary sources near site 1 are different from site 2. Site 1 is surrounded by the Hazar Group consisting of carbonates and clastic sediments and by the Maden complex composed of various clastics and occasional volcanoclastics, andesite and diabase. The sediment sources of site 2 are much more enriched in mafic and volcanic rocks (gabbros, basalt and andesite) of the Yüksekova Melange (Herece, 2008).

Detailed clay mineralogy was obtained on bulk samples from the turbidites and hemipelagic sediments. The samples were decarbonated with a $0.1 \mathrm{~mol} / \mathrm{L}$ solution of $\mathrm{HCl}$ and sieved under 2 $\mu \mathrm{m}$ by settling in a water column (Moore \& Reynolds, 1997). Fine grain samples were mounted as oriented aggregates on glass slides and three X-ray patterns were recorded on each sample: one on the air-dried sample $(\mathrm{N})$; one after solvation by ethylene-glycol for $24 \mathrm{~h}$ (EG); and one after heating at $500^{\circ} \mathrm{C}$ for $4 \mathrm{~h}(\mathrm{H})$. The background noise of the X-ray patterns was removed and semi-quantitative estimation of the main clay species were obtained using the DIFFRACplus EVA software (Bruker) according to the methods of Biscaye (1965) and Thorez (1976).

Grain-size distributions were measured on sediment samples every $2 \mathrm{~mm}$ within the turbidites and every $5 \mathrm{~mm}$ in background sediments using a Malvern Mastersizer 2000 laser diffraction analyser (Malvern Instruments Limited, Malvern, UK). From these measurements the percentages of particles smaller than $7.5 \mu \mathrm{m}$ (clay), between $7.5 \mu \mathrm{m}$ and $60 \mu \mathrm{m}$ (silts) and higher than $60 \mu \mathrm{m}$ (sands) were extracted.

Thin sections were made by resin impregnation of sedimentary slabs extracted from the cores using an $8 \mathrm{~cm}$ long, $3 \mathrm{~cm}$ wide and $1.5 \mathrm{~cm}$ thick U-channel (following the method of Van Daele et al., 2014a). The polished thin sections were analysed under a microscope and a binocular to characterise the turbidites with a single fine silt-sized grain resolution.

This article is protected by copyright. All rights reserved. 
A radiocarbon dating was done on a wood remain found in the hemipelagic sediment of site 1 and gave a calibrated age of $752 \pm 20$ years BP at $90 \mathrm{~cm}$ of depth on the short core (Fig. 4). Removing the thicknesses of the instantaneous turbiditic events, $c a 75 \mathrm{~cm}$ of background sedimentation is left which corresponds to $c a 750$ years covered by the sediment record found in the short cores. This number is consistent with the rate of $1 \mathrm{~mm} /$ year calculated by Garcia Moreno et al. (2011) for the western south part of the basin.

\section{RESULTS}

\section{Study sites: morphology and sources of sediments using the geophysical data set}

The three study sites are located in the western part of Lake Hazar (Fig. 1). No evidence of recent slope failure was observed from the lake bathymetry that was reconstructed from the dense grid of seismic lines (Figs 2 and 3).

\section{Proximal Study Site: Site 1}

Site 1 (99 m depth) is located $250 \mathrm{~m}$ to the north of the faulted southern steep lake margins ( $c a 15$ to $30^{\circ}$ ). These margins show different sediment covers (Fig. 3). The upper part has a thin lacustrine and alluvial sedimentary cover fed by a unique minor ephemeral river draining terrains of the Hazar calcareous group and Maden melange which may supply the basin with coarse sediments. The intermediate part of the steep margins at this site is covered by a thin sedimentary veneer. The lower part of the margins shows a thicker sedimentary cover composed of lacustrine and deltaic sediments.

Site 1 is also located just to the south-west of the Small-elongated Basin (SeB in Fig. 1), a small pullapart basin that links the Shallow Basin to the Deep Basin. The SeB is bordered on all sides by small reliefs linked to active faults (Figs 2 and 3).

Site 1 is unlikely to be reached by sediment flows originating from the Kurk delta or the two smaller deltas along the northern margin (Figs 2 and 3, Sp5). These flows would run through the Shallow Basin and could only ultimately reach the Deep Basin through the Small-elongated Basin.

This article is protected by copyright. All rights reserved. 
Sites 2 (72 $\mathrm{m}$ water depth) and 3 (63 $\mathrm{m}$ depth) are located in the central flat area of the shallow basin and are relatively distal from the margins (Fig. 1). Physiographic differences between those two sites are thus minor. Site 3 is located in a more proximal position, ca $1.5 \mathrm{~km}$, to the Kürk delta slopes while site 2 is located less than $1 \mathrm{~km}$ from to the promontory built on the southern lake margins (Figs 2 and $3)$.

The largest clastic input of these two sites comes from the Kürk River, which built a wide composite delta bound to the south by an active fault (Figs 1 and 2; Garcia Moreno et al., 2011, Eriş, 2013). Potential reworking of the $c a 100 \mathrm{~m}$ long, $c a 13 \mathrm{~m}$ high delta front would thus primarily affect site 3 compared to site 2. Both sites are located close to a series of small stacked deltas on the lake northern margin (Deltas 1 and 2 on Fig. 2). The sites are also close to the promontory, which features steeper slopes than the deltas and is crossed by several fault splays (Fig. 2). Near site 2, the promontory slopes are covered by lacustrine sediments (Fig. 3).

\section{Correlation between the cores and the study sites}

Cores from the three study sites were correlated based on sedimentological variations resulting from processes affecting the entire lake. Several proxies were used (Fig. 4): grey levels extracted from the X-ray images, $\mathrm{Ca} / \mathrm{Al}$ ratio profiles, carbonate and organic matter contents obtained independently by loss on ignition and $\mathrm{Br}$ counts (a proxy for organic matter content for site 3; Ziegler et al. 2008).

All cores show similar variations in their carbonate and organic matter contents independently from the observed turbidites. Carbonates and organic matter profiles depict lower values along the upper half of the cores ( $\mathrm{ca} 50$ to $45 \mathrm{~cm}$ ) compared to the lower half. This major change in the sedimentation is attributed to the lake level rise that started around AD 1795 (Tonbul \& Yiğit, 1995), after the AD 1789 earthquake (Ambraseys, 1989). Because there are very few carbonaceous rocks in the Hazar catchment, precipitation of calcite is likely to be controlled by biogenic and physico-chemical factors. 
Large changes in water volume would strongly affect this process: while a lowstand period can induce concentration processes (for example, higher $\mathrm{pH}$, ion concentration and $\mathrm{CO} 2$ solubility), a highstand period can trigger dilution processes, resulting in more and less carbonates, respectively. The radiocarbon dating on a terrestrial sample from $91 \mathrm{~cm}$ depth of the short core from site 1 gives a calibrated age of AD 1217 to 1291 (Fig. 4). This date implies that high carbonate and organic matter deposition occurred during the lowstand period corresponding to the occupation of an Armenian monastery from the $12^{\text {th }}$ to the $18^{\text {th }}$ Century (Hubert-Ferrari et al., 2017). The coincidence of high inorganic and organic carbon may be related to the adsorption of dissolved organic matter to $\mathrm{CaO} 3$ (Ulhman \& Horn, 2001).

The core correlation implies that the sedimentation rates at the three sites are nearly the same. This was confirmed by the long core correlation as well as by the similar thickness of the Holocene sedimentary unit (Garcia Moreno et al., 2011). The focused event sets B, C and D are thus found in the study sites at similar depths, but with different levels of expression (Fig. 4). The event fingerprint is more pronounced at site 1, which comprises the highest number of turbidites per set. For instance, event set B includes four turbidites within site 1 and only two turbidites within sites 2 and 3 (see Fig. 4).

\section{Sets of turbidites: general results}

This section presents the results issued from the quantitative analyses made along the cores collected at the three study sites (Figs 5 and 6).

\section{Magnetic susceptibility}

Magnetic susceptibility peaks occur coincident with most of the turbidites and are particularly high in event set D for the three sites (Figs 5 and 6). These variations reflect grain-size and composition modifications characterising the turbidites compared to the background sediments. 


\section{Geochemical composition}

Geochemical ratios show systematic peaks of $\mathrm{Fe} / \mathrm{Ca}$ and $\mathrm{Ti} / \mathrm{Ca}$ along most of the turbidites and correspond to magnetic susceptibility peaks. However Fe and Ti counts show no increase, the ratios change thus highlights mostly a variation of calcium composition compared to the background sedimentation.

Isotope analyses $\left(\delta^{13} \mathrm{C}, \mathrm{C} / \mathrm{N}\right.$, see Table $\left.1 \mathrm{a}\right)$ in site 1 show a very uniform organic content, i.e. identical within the background sediments and the turbidites. The signature of the organic matter with a $\mathrm{C} / \mathrm{N}$ ratio of 8.5 and a $\delta^{13} \mathrm{C}$ of $-25.5 \%$ points to lacustrine algae and thus to a lacustrine origin of the turbidites (Meyers \& Teranes, 2001).

\section{Mineralogical composition}

$\mathrm{X}$-ray diffraction measurements show that the mineralogical composition of the background sediments and the turbidites are similar within an individual site (Table 1b). Compared to hemipelagic sediments, the turbidites are slightly enriched in quartz and plagioclase at site 2 and very slightly enriched in quartz, plagioclase and K-feldspar at site 1 . The source of the sediment flows reaching site 1 and 2 is thus similar to the source of the suspended hemipelagic sediment deposited at the sites respectively.

Study sites 1 and 2 show a different mineralogy, which implies that sediment sources of suspended hemipelagic sediment and of the sediment flows are distinct between the sites. The sediments from site 2 have half the amount of $\mathrm{K}$-feldspar, and twice the amount of plagioclase and muscovite compared to site 1 . In addition, aragonite and pyrite are present only in the sediments from site 1 . This is linked to differences in geology near the sites. Upstream site 1, the Hazar calcareous formation and the Maden Melange would provide the aragonite. Site 2 reflects the geology of the Kürk river catchment where the Guleman ophiolotic complex is dominant and provide less K-feldspath and more plagioclase and muscovite (Herece, 2008).

This article is protected by copyright. All rights reserved. 
X-ray diffraction measurements also show that around $40 \%$ of the minerals found in the sediments, both background and turbidites, correspond to clay minerals. In particular, detailed clay mineralogy conducted in hemipelagic sediments above and below the turbidite D1 reveals three main clay minerals (Fig. 10): kaolinite $(40 \pm 1.2 \%)$, illite $(33 \pm 0.4 \%)$ and a mixture of chlorite and swelling chlorite $(27 \pm$ $0.4 \%)$. Clay fraction comprised in the clayey sand turbidites is mostly kaolinite (37\%), chlorite (32\%) and illite (31\%). Layers enriched in kaolinite will appear whiter and the ones enriched in chlorite will appear darker, for example see thin section of D1 on Fig. 9 (Kadir \& Akbulut, 2009; McBride, 1974). The main mineralogical difference between the hemipelagic sediments and the turbidites is thus the proportion of chlorite. In the coarse base of the turbidites, swelling chlorite is absent and the shape of the chlorite peak (14A on Fig. 10) is narrower implying that the space between the mineral sheets is not occupied by water.

\section{Grain-size analysis}

Grain-size distributions reveal that the background sedimentation between the turbidites is unimodal and centred on $8 \mu \mathrm{m}$ in the three sites, with a slightly higher sandy content for site 1 compared with the other sites (Figs 5 to 10). The base of each event deposit is characterised by coarser sandy particles mixed with mud. This sandy supply is then overlaid by an increase of the fine fraction for some of the turbidites, for example, within the event set D of the 3 sites. The transition between the sandy and finer layers is very sharp and can be compared to the 'grainsize breaks' of type 5, i.e. mud-rich sand overlain by mud, described by Stevenson et al. (2012).

Both XRD and geochemical measurements are coherent with the grain-size variations (Figs 5 and 6). Around $40 \%$ of the minerals found in the sediments correspond to clay minerals whereas the same amount of particles smaller than $7.5 \mu \mathrm{m}$ have been measured independently by grain-size analysis. Moreover, coarse particles supply in the event deposits is highly correlated with peaks of magnetic susceptibility and of iron and titanium to calcium (Figs 5 and 6) and with a slight enrichment in terrigenous minerals such as quartz, plagioclase, K-feldspath (Table 1).

This article is protected by copyright. All rights reserved. 


\section{Bioturbation}

Bioturbation in the form of vertical burrows is present throughout the turbidites and at their base (Figs 8 to 10). Burrow length varies from 1 to $10 \mathrm{~mm}$ and they are filled with similar particles to the above layer, i.e. where they originate. The burrows were formed after the event deposition and are probably related to oligochaete worms and chironomidae larvae present at the lake bottom (Timm et al., 2013). It is not always clear to distinguish these vertical burrows from possible fluid escape features. The latter generally show a funnel shape, with vertical breaks filled with mud in the coarser basal layers (for example, Fig. 8).

Only two types of fossil remains were found in the turbidites. Firstly, ostracodes without any particular distribution were found in all the thin sections (for example, Figs 9 and 10). Secondly chironomidae larvae were found, characterised by a red colour and a length between $1 \mathrm{~mm}$ and $10 \mathrm{~mm}$ (for example, Figs 7 and 8; Charles et al., 2004). Although planktonic studies documented the existence of diatoms in Lake Hazar (Koçer \& Sen, 2014), they were not detected in the sediments. The high $\mathrm{pH}$ of the lake water probably led to the complete dissolution of their frustules that cannot be recognised in the thin sections.

\section{Characterisation of the turbidites per event set and per study site}

The upper parts of the cores are composed of the event set A, which was not studied in detail for three reasons. Firstly, it was difficult to unambiguously correlate the turbidites in the different cores due to coring artefacts at the core top usually encountered with a sampling system by piston. Secondly, there has been a set of large human impacts on the lake since the construction of the railway in 1950 that complicated the record interpretation at the different sites. Event sets B, C and D are too deep to be affected by coring artefacts and recent human impacts and have therefore been the focus of this study. Thirdly, there was a large lake level increase starting at the beginning of the $19^{\text {th }}$ Century, preceded by a $12^{\text {th }}$ to $18^{\text {th }}$ Century lowstand that was marked by the construction and occupation of an Armenian 
monastery (Hubert-Ferrari et al., 2017). In order to unambiguously compare the different event sets, the present study focuses on the same lowstand period during which events B, C and D occurred.

Set of event deposits B (Fig. 7)

The event set B comprises four turbidites at site 1 and two turbidites at sites 2 and 3 (Figs 4 and 7). Turbidites at site 1 are overall coarser than the ones found in the other sites.

At site 1, turbidite B1 is composed of a very sparse and discontinuous clayey silt layer, overlying a $1 \mathrm{~cm}$ thick clayey layer. Turbidite B2 includes four different layers: two graded clayey sand layers sharply separated by a $2 \mathrm{~mm}$ thick clayey layer and capped by a $3 \mathrm{~mm}$ thick dispersed clayey silt layer. Turbidite B3 is composed of a $4 \mathrm{~mm}$ thick normally graded clayey sand layer and capped by a $3 \mathrm{~mm}$ thick clayey layer. The basal sandy layer is disturbed by vertical breaks of around $1 \mathrm{~mm}$ wide. Turbidite $B 4$ is composed of an ungraded clayey silt layer and is highly bioturbated.

At site 2, turbidite $B 2$ shows an ungraded $1 \mathrm{~mm}$ thick clayey silt basal layer capped by a $2 \mathrm{~mm}$ thick silty layer. The grain-size distribution is unimodal with a gentle coarsening-upward trend towards the base. B2 is entirely deformed, i.e. it depicts a spiral at the right of the photograph (Fig. 7). This deformed feature is present both in the short and long cores, which means that a core disturbance can be ruled out. Turbidite B3 is made of a very thin and discontinuous silty layer.

At site 3 (Fig.6), the lower turbidite corresponding to B2 of site 2 is also the thickest one. The basal silty layer is clearly visible in the $\mathrm{X}$-ray image.

Set of event deposits $C$

Site 1 shows eight turbidites (Fig. 8): Cl to C6 are similar and composed of an ungraded thin clayey silt layer. Event deposit $C 7$ is very deformed and includes a thin clayey layer in between two graded layers made of sand and clay. Event deposit C8 consists in a dense and clayey sand layer capped by a thin clayey layer (Fig. 8).

This article is protected by copyright. All rights reserved. 
Site 2 does not feature any visible turbidite within the corresponding depths of event set $\mathrm{C}$ occurring at sites 1 and 3 (Fig. 6). At site 3, event set $\mathrm{C}$ is composed of a homogeneous muddy silt layer (Fig. 8).

Set of event deposits D (Figs 9 and 10)

Event set D is composed of two turbidites in the three study sites. All of the turbidites are characterised by a graded basal clayey sand layer with a bimodal distribution and a clear grainsize break with the background sediment.

The two turbidites of site 1 (Fig. 9) consist of a dense and clayey sand layer overlain by a thin clayey layer beneath a thicker silty clay layer. The basal coarse layer of $D 1$ is laminated, i.e. made of thin layers of clay injected into the sandy base (see radiograph). The basal coarse layer of D2 is highly convoluted and shows strong thickness changes.

In sites 2 and 3 (Fig. 10), the basal clayey sand layer of the turbidites is capped by a $1 \mathrm{~cm}$ thick clayey layer creating a sharp grain-size break. This mud cap is laminated and depicts two colours of clay. The basal clayey sand layer of $D 1$ is composed of vertical breaks. The coarse basal layer of D2 contains small ripple bedforms characterised by very thin laminations (see thin section and CT scan image of both sites). It is topped by a non-laminated sandy layer underneath a mud cap.

\section{INTERPRETATION}

\section{Sediment sources and triggering mechanisms}

Turbidity currents can be triggered by a wide variety of processes, for example, slope failures of submerged basin margins and deltas, bedload plunging and fall-out of suspended plume from river discharge, sediment resuspension by storm waves or earthquakes, oceanographic processes related to tides and fresh-saline water interface (Piper \& Normark, 2009, Clare et al., 2016). Oceanographic processes can directly be ruled out in the context of this lacustrine study.

This article is protected by copyright. All rights reserved. 
Possible triggering mechanisms for the studied turbidites can then be grouped into two types of sediment sources: (i) sediment issued from the river discharge; and (ii) previously deposited lacustrine sediments. Three main arguments point to a lacustrine source for the turbidites without external supply from the rivers. Firstly, the turbidites show a mineralogy and $\mathrm{C} / \mathrm{N}$ ratio comprised between 7.1 and 8.6, mostly identical to the background hemipelagic sediments (Table 1). The range of $\mathrm{C} / \mathrm{N}$ ratios is generally 3 to 9 for aquatic sources, 10 to 20 for mixed aquatic and terrestrial sources and $>20$ for terrestrial plants (Meyers, 1997). Secondly, turbidites in Lake Hazar systematically contain ostracod shells and chironomid remains that are specific to the lake. Thirdly, the grain-size trend observed in the coeval turbidites between the three study sites means that an origin from the main river Kürk can be ruled out. Indeed, the turbidites are generally much coarser in site 1, which is not connected to any major fluvial source compared to sites 2 and 3, which are closer to the Kürk River (see Event set D, Figs 9 and 10).

Turbidites therefore have a lacustrine source and must relate to remobilisation of previously deposited subaqueous sediments. Given that Lake Hazar is crossed by the East Anatolian Fault system, i.e. source of $\mathrm{M} c a 7$ earthquakes and that it is located close to a number of other seismic sources capable of generating $M \geq 7$ earthquakes (Cetin et al., 2003), earthquakes are a highly plausible trigger for these remobilisations. Moreover, earthquakes have been shown to explain liquefaction features and soft-sediment-deformation observed in the Kürk Delta deposits in a recent study by Hubert-Ferrari et al. (2017). Assuming an earthquake trigger, two possible mechanisms could explain the turbidites presented here.

Firstly, earthquakes could have caused a lake-wide resuspension of surficial sediments such as described by Marco et al. (1996) and Hubert-Ferrari et al. (2012). However, remobilisation of the very fine sediments at the lake bed would not explain the grain size profiles of the turbidites which consistently have silt and sand.

Secondly, although the available geophysical data does not indicate slope failures that are thicker than $1 \mathrm{~m}$, an increasing number of studies in seismically active areas have found evidence for very shallow (often $<10 \mathrm{~cm}$ ) slope failures (e.g. Forsberg et al., 2016, McHugh et al., 2016, Moernaut et al., 2017). 
Moernaut et al. (2017) showed in Chilean lakes that earthquakes could trigger a shear strength reduction in water-rich top sediments that moved them downslope forming turbidity currents. The present authors propose that such shallow slope failures are the most plausible mechanism at the origin of the studied turbidites. These failures are below the resolution of the stratigraphy imaged by the geophysical data presented here (i.e. $c a 5 \mathrm{~m}$ of horizontal resolution and $1 \mathrm{~m}$ of vertical resolution on the lake slopes). Shallow slope failures can also explain the low thickness of the observed turbidites. Indeed, the largest studied turbidite is $3 \mathrm{~cm}$ thick and most of them are 1 to $2 \mathrm{~cm}$ thick; the $c a 5 \mathrm{~m}$ long cores at sites 1 and 2 show no thicker event deposits. Considering turbidite thickness as a relative proxy for flow volume, the thin turbidites imply that a small volume of sediment was reworked and suggest again shallow failures running downslope.

\section{Flow dynamics at the origin of the event deposits unravelled by comparison with flume experiments}

This study derives the dynamics of the turbidity currents events using four experimental studies focused on sediment flows and water mixtures made of mud, i.e. cohesive particles and granular particles, i.e. non-cohesive (Amy et al., 2006; Sumner et al., 2009; Baas et al., 2011 and Manica, 2012).

The four flume experiments used a range of grain sizes similar to the grain-size distribution characterising the deposits herein, from clay particles to sand (Table 2; Amy et al., 2006; Sumner et al., 2009; Baas et al., 2011 and Manica, 2012). This allows a comparison between field-scale deposits in Lake Hazar and deposits obtained in laboratories. Silt (i.e. 7.5 to $60 \mu \mathrm{m}$ ) and sand particles (i.e. $60 \mu \mathrm{m}$ ), defined here are characterised by a non-cohesive behaviour, as observed in the experiments. The $<7.5 \mu \mathrm{m}$ fraction present in the studied turbidites matches with the clay percentages obtained independently by mineralogical measurements.

Three main types of turbidites are distinguished in this study, relying on four criteria: the presence of grading, the thickness of the event deposits, the grain size of the particles and the presence of sedimentary structures (Table 3).

This article is protected by copyright. All rights reserved. 
Type 1: Ungraded clayey silt layer sometimes overlain by a mud cap

Turbidites of type 1 correspond to 1 to $3 \mathrm{~mm}$ thin layers made of silt to fine sand size particles mixed with clay (for example, B2 and B3 of site 2, and B1 and B4 of site 1 on Fig.7; C of site 3 and $\mathrm{C} 1$ to $\mathrm{C} 6$ of site 1 on Fig. 8). These basal layers are ungraded, as demonstrated in the high resolution imagery (thin sections and CT scan). A mud cap with a variable thickness is sometimes present.

Type 1 deposit of this study is similar to several experimental deposits characterised by a lack of grading (see Table 3). Regarding the flow characteristics at the origin of these referenced experimental deposits, type 1 herein is inferred to result from a laminar flow (Amy et al., 2006; Sumner et al., 2009; Baas et al., 2011 and Manica, 2012). The latter involves cohesive forces with sufficient yield strength to suspend all the particle sizes. This non-Newtonian behaviour prevents the settling of coarser particles and suppresses the particle segregation, producing an en masse deposition (Baas et al., 2011). The laminar character is well attested to in the studied deposits through two characteristics. Firstly, there is a lack of grading in the clayey silt layers. Secondly, entire larvae of chironomids have been found in some turbidites (for example, C6 and C8 of site 1, see Fig. 8). A turbulent flow is unlikely to have kept such fossil remains intact since their segments are very fragile.

The presence of mud caps overlying the ungraded basal layers can be explained by three different mechanisms. Firstly, the process of elutriation corresponds to the flushing out of the clay from lower levels during the development of vertical pipes (Amy et al., 2006). This creates a counterflow able to transport the finer particles to the top. Such fluid escape features have been evidenced in the studied deposits (for example, Fig 8). The second mechanism is related to the evolution of the flow responsible for the deposition of the basal ungraded layer. This flow can be transformed into a dense thinner fluid mud layer during its later stages (i.e. tail). The two parts in turbidites of type 1 may thus represent the main body and the tail of the same sediment flow. Thirdly, another flow from another source carrying only clay particles may also have deposited this mud cap by en masse freezing. 


\section{Type 2: Partially graded clayey sand layer overlain by a mud cap}

The second type of turbidite comprises a discontinuous basal clayey sand layer overlain by a $1 \mathrm{~cm}$ thick mud cap. The sandy basal layer is characterised by an absence of grading in the lower basal millimetres, evolving into normal grading in the upper millimetres. This basal layer does not show any structures, i.e. no laminae or convolution features (for example, C8 at site 1 on Fig. 8 and D1 at sites 2 and 3 on Fig. 10).

A type 2 deposit is here attributed to a transitional sediment flow in which there is a balance between cohesive and turbulence forces (Table 3). The referenced experiments have shown that the settling of such flows occurred through first en masse consolidation and second incremental aggradation while the flow cohesion is no longer able to overbalance turbulence (Table 3). The mud cap overlying the basal sandy layer may have been settled by the same processes described in the mud caps of type 1 turbidites.

\section{Type 3: Structured graded clayey sand layer overlain by a mud cap}

Turbidites of type 3 include the following intervals (see Table 3): (i) a basal graded clayey sand layer displaying laminae; (ii) a graded clayey sand layer without lamination; and (iii) a mud cap layer generally thicker than the basal layer (for example, B2 and B3 of site 1 on Fig. 7; C7 of site 1 on Fig. 8; D1 and D2 of site 1 on Fig. 9; D2 of sites 2 and 3 on Fig. 10).

Turbidites of type 3 are attributed to a flow where turbulence mostly outbalances cohesive forces. Turbulence is indeed demonstrated in this third type by the following characteristics.

Firstly, the deposits show a normal grading and thin laminations. Normal grading is due to the gradual settling of sandy particles from the turbulent flow as it decelerates and stops (Sumner et al., 2009). Laminations (Event D2 of sites 2 and 3; Fig. 10) are built by the settling of silt flocs alternating with the gradual settling of clay flocs (Stow \& Bowen, 1978, 1980; Baas et al., 2011).

Secondly, turbidites of type 3 show erosional boundaries between the base and the hemipelagic sediments, which attest to a reworking of the lake floor by the flow. This interaction flow-floor was generated in the experiments under a turbulent regime (Sumner et al., 2009; Baas et al., 2011). Basal

This article is protected by copyright. All rights reserved. 
scouring is difficult to evidence in cores, but a wavy erosional contact of the basal coarse layers with the hemipelagic sediments and with the top non laminated sand layer in turbidites D2 of sites 2 and 3 was imaged here (Fig. 10). This wavy contact is not thought to be a coring artefact since it has been observed in the lower part of the gravity cores where deformation is minimal. It is inferred that this overlying sand layer scoured the initial bedform during either a later stage of a single flow or a by another flow after a certain lapse of time. Erosion and incorporation of the weak water-rich surface sediments settled at the lake floor can also explain incorporation of mud pockets within sandy layers such as in C7 and D2 events of site 1 (Figs 8 and 9).

\section{Turbidites at Lake Hazar and classical models}

Correlation of the three types of turbidites described above with models widely recognized in the literature (Piper, 1978, Piper \& Stow, 1984, Talling et al. 2012) is not straightforward. Overall, the turbidites found in Lake Hazar are very thin, i.e. 1 to $2 \mathrm{~cm}$ thick, compared to the theoretical models and study cases found in the literature, with a few examples of thin, 2 to $5 \mathrm{~cm}$, bedded turbidites cited by Piper \& Stow (1984).

Turbidites of type 1 may relate to low-strength cohesive debrites (Talling et al., 2012) where cohesion is able to support all particle sizes and is produced by transformation of an initially turbulent flow that reaches more distal locations. Examples of low strength cohesive debrites cited by Talling et al. (2012) are however much thicker than the present turbidites of type 1.

Turbidites of type 3 show a stratigraphy similar to mud turbidites (Piper, 1978) or densite mud (Talling et al., 2012): (i) a laminated graded interval TE-1; (ii) a graded massive interval TE-2; and (iii) a massive ungraded mud interval TE-3 that is usually much thicker than the other intervals. However, mud turbidites and densite mud as defined by Piper (1978) and Talling et al. (2012) have no sand content while the present turbidites of type 3 show a high proportion of clay and sand even for the coarsest events (for example, turbidites D1 and D2 on Fig. 6)

This article is protected by copyright. All rights reserved. 
Turbidites of type 2 stand in between the two main regimes widely recognized in sediment flows, i.e. cohesion and turbulence. Hence, this study shows evidence for the occurrence of transitional flows in a field-scale basin.

\section{Event sets variability and evolution of the flow}

\section{Comparison of the sediment record between the three study sites}

Figure 11 provides a schematic summary showing the occurrence of the three types of turbidites observed in the three study sites. Overall, there is a greater evidence of flows based on deposits in proximal site 1 compared to sites 2 and 3 given the higher number of turbidites found in site 1 . Erosion and flow bypass are very unlikely to explain the lower number of turbidites at sites 2 and 3 since they are both more distal to the sources and lie in a flat area of the lake. This suggests that flows were more frequent and/or less diluted in proximal site 1 . Flows at site 1 were also more competent, i.e. able to support coarser particles (Stacey \& Bowen, 1988), because the turbidites are generally coarser compared to sites 2 and 3. Regarding event sets B and C, turbidites of type 2 and 3 are only found in site 1 while the other sites only comprise turbidites of type 1 . Event set D is characterised by turbidites of type 2 and 3 in the three sites, with coarser grain sizes for site 1.

\section{Event expression in relation to the basin physiography}

Several factors related to the Lake Hazar settings can explain the variability of the sedimentary record observed between the three sites. Firstly, the intensity of the triggering mechanism, i.e. ability to mobilize the sediment cover on slopes, may partly be responsible for the divergence observed. However site 1 is located only ca $3.5 \mathrm{~km}$ away from site 2 and the intensity of the external event responsible for the sediment reworking would not be drastically different. Secondly, the physiography surrounding the sites is significantly different (Fig. 11). Site 1 is closely (i.e. 200 to $700 \mathrm{~m}$ ) surrounded by a large number of steep (i.e. 15 to $30^{\circ}$ ) faulted slopes while sites 2 and 3 lie further (i.e. 1 to $2 \mathrm{~km}$ ) from the sources characterised by more gentle slopes (Figs 2 and 11). Dilution of the flows reaching sites 2 and 3 is thus higher compared to proximal flows reaching site 1 . Thirdly, as the sediment sources are distinct between site 1 and the two other sites, the volume 
available for remobilization and the grain-size composition of the sources are also different. Sources for site 1 are steep lake margins covered by coarse grains while most of the sources for sites 2 and 3 are sediments sorted on the deltaic slopes surrounding the sites.

In proximal site 1, turbidite B2 is composed of a clay layer sandwiched between two layers of muddy sand while the top is a sparse silt unit (Fig. 7). A similar silt unit also tops D1 and D2 from site 1 (Fig. 9). These complex configurations can be explained by two processes related to the basin physiography at this proximal site. Firstly, multiple slopes may have failed within short period of time and deposited distinct layers during a single event, as seen in Van Daele et al. (2015) and Avsar et al. (2015). Secondly, multistage remobilizations of one specific source, such as evidenced by Hunt et al. (2011), is possible. A third process called flow reflection, occurring when a flow runs up a slope and then collapses backwards (Kneller \& McCaffrey, 1999, Tripsanas et al., 2004), has been envisaged. However, site 1 is only surrounded by steep slopes to the south, the only slopes steep enough to generate a flow reflection being $4 \mathrm{~km}$ north to the site (Figs 3 and 11).

\section{Flow behaviour in relation to clay content}

The high clay content of the flows is also inferred to have played a major role in the observed deposits. Flume experiments have indeed shown that flow behaviour could evolve with time as a result of the clay fraction carried (Amy et al., 2006; Sumner et al., 2009; Baas et al., 2011; Manica, 2012). As a sediment flow travels clay flocs are created by strong cohesive bonds, thus increasing the flow viscosity and damping the turbulence, a process called viscosity bifurcation by Coussot et al. (2002). In the present study, the longest travel time would be for flows arriving at the distal sites with respect to their sources, for example a flow coming from the Kürk Delta slopes would run ca 3.5 $\mathrm{km}$ to reach site 2 (Fig. 11). This could explain why these sites mostly comprise turbidites of type 1 for coeval event sets B and C compared to site 1 .

This article is protected by copyright. All rights reserved. 
The variation of clay composition observed in some mud caps is also interpreted to result from a flow evolution. For instance in the event D1 of the distal sites 2 and 3 (Fig. 10), the darker basal mud cap, rich in chlorite, would have been carried by the early flow stages (i.e. the head) whereas the upper, lighter mud cap, rich in kaolinite, is attributed to the late flow stages (i.e. the tail) allowing more time to flocculate.

\section{DISCUSSION}

\section{What are the sources and triggers for thin turbidites found in Lake Hazar?}

Sources for the studied thin turbidites correspond to the surficial sediment cover found on Lake Hazar slopes. Sediment sources are different from one study site to another (Fig. 11). Sources for proximal site 1 mainly correspond to a series of very steep 15 to $30^{\circ}$ faulted slopes characterising a sub-basin hanging slightly above the Small elongated Basin (Fig. 11). Sources for distal sites 2 and 3 are steep 7 to $12^{\circ}$ slopes of the promontory, and more gentle 3 to $8^{\circ}$ slopes of the Kürk Delta and two small northern deltas (Figs 2 and 11).

Surficial sediment of these slopes is proposed to have been mobilised by $<1 \mathrm{~m}$ thick slope failures, i.e. shallow failures, that have not produced any visible headscarp in the data available. Mobilisation of the most superficial part of the subaqueous slopes would then have generated long run-out turbidity currents as documented by Forsberg et al. (2016) in a Norwegian lake or by Moernaut et al. (2017) and McHugh et al. (2016) in active seismic areas.

\section{Why are the thin turbidites organised into closely spaced thin beds within event sets?}

This study evidenced multiple closely spaced thin turbidites within three sets. Event set B comprises two to four turbidites depending on the study sites, event set $\mathrm{C}$ includes eight turbidites in site 1 and only one thin turbidite in site 3 while event set D comprises two turbidites in the three sites (Fig. 11). Based on a sedimentation rate of $1 \mathrm{~mm} /$ year (Garcia Moreno et al., 2011) confirmed by the radiocarbon dating (see Methods), these three event sets are separated from one another by 10 to 15 $\mathrm{cm}$ of background sediments, i.e. 100 to 150 years. Within each event set, individual turbidites are 
separated by 1 to $2 \mathrm{~cm}$ of background sediments (i.e. showing a different composition from the turbidites), which correspond to 10 to 20 years if a sedimentation rate returning to normal conditions between the event beds is assumed.

Given the high seismicity of the region, it is plausible that the turbidites relate to shallow slope instability triggered by highly recurrent earthquakes (Ambraseys, 1989; Cetin et al., 2003). Hence, multiple earthquakes that occurred with lapses of time between 10 and 20 years within a sequence covering a century is a possible explanation, because the East Anatolian Fault tends to generate earthquakes in sequences (Nalbant et al., 2002). For example, a sequence of 10 earthquakes occurred within around 150 years over the $18^{\text {th }}$ and $19^{\text {th }}$ Century along the East-Anatolian Fault Zone (Nalbant et al., 2002). However, correlating with certainty each of the event sets with historical events would require a robust age control by absolute dating, which is not the focus of the present study.

Some individual turbidites show stacked beds without any return to hemipelagic sedimentation (for example, Fig. 7, Event B2 of Site 1). Multistage failures of a single source as evidenced by Hunt et al. (2011) or multiple slopes failing concurrently as seen in Van Daele et al. (2015) and Avsar et al. (2015) are two possible explanations for these configurations.

How did the flows behave and how did their behaviour change in relation to the basin physiography?

Thin clayey sand turbidites from Lake Hazar are interpreted to show evidence for three types of flow behaviour: (i) laminar regime dominated by cohesion; (ii) transitional regime between turbulent and laminar states; and (iii) turbulent regime. These flow behaviours are found in the three study sites within the basin and their distribution differs from one event set to another (Fig. 11).

At proximal site 1, which is surrounded by several steep faulted slopes, event sets B and C include the three types of turbidites described in this study (Fig. 11). Such diversity observed at an individual site implies that turbidity currents behave very differently from one event to another. This behaviour

This article is protected by copyright. All rights reserved. 
diversity may relate to the occurrence of slope failures at different elevations on the slopes surrounding site 1. Activation of flows from different elevations can result in different flow velocities and run-out distances, i.e. shorter/longer time for transformation of flow regime.

At distal sites 2 and 3, event sets B and C only bear evidence for laminar flows that have been able to sustain until more distal locations with respect to their own sources (Fig. 11). The present authors infer that these flows were turbulent in their early stages and underwent flow transformation until reaching sites 2 and 3.

Event set $\mathrm{D}$ evidences for turbulent and transitional regime in the three sites, with a coarser fraction for site 1, compared to sites 2 and 3. Overall, event set D shows the highest intensity, i.e. highest thickness and coarsest grain sizes, in the three sites compared to event sets B and C (Fig. 11). This difference of event expression across the whole basin is explained by the intensity of the trigger. It is inferred here that the trigger for event set $\mathrm{D}$ was able to mobilise the lacustrine sources with a higher intensity compared to event sets B and C, thereby triggering more energetic flows for the three sites.

\section{Do the deposits from Lake Hazar validate flume experiments found in the literature?}

This study compared the turbidites found in Lake Hazar with four experimental studies centred on the presence of clay within turbidity currents (Amy et al., 2006; Sumner et al., 2009; Baas et al., 2011; Manica, 2012; Tables 2 and 3). The four experiments generally observed turbulence-dominated flows evolving into cohesive flows as they added clay particles. This flow regime transition in the experiments resulted in distinct deposits characterised by turbulence and laminar evidence such as the presence or absence of grading. Turbidites from Lake Hazar cover the general range observed in the experimental deposits: type 1 resulting from a cohesive flow; type 2 from a transitional flow; and type 3 from a turbulence-dominated flow (Table 3).

This article is protected by copyright. All rights reserved. 
However, the turbidites of type 3 are attributed to a turbulent flow even though their clay content is high, reaching up to $30 \%$ of the total sediments (Figs 5 and 6). This is not consistent with the four experiments which showed that only a few percent of clay was required to damp turbulence and settle ungraded deposits such as type 1 here. This divergence is explained by two main groups of controlling factors that have not been fully considered in the four experimental studies: (i) water chemistry (i.e. salinity, $\mathrm{pH}$, organic matter content and temperature); and (ii) clay properties (i.e. amount and size of clay particles, type of clay minerals). It is indeed largely recognised that the degree of clay flocculation, and therefore the viscosity of a clay-rich suspension, strongly depends on these factors (e.g. Whitehouse et al., 1960; Edzwald \& O'Melia, 1975; Chamley, 1989, Mietta et al., 2009, Gupta et al. 2011, Pourmohammadbagher \& Shaw, 2016).

Water chemistry of Lake Hazar significantly differs from the water used in the four experiments (Table 2). Lake Hazar water has a salinity of $16 \%$ and is highly alkaline with a $\mathrm{pH}$ of 9.3 (Sen et al., 2002, Eris, 2013). Moreover, Lake Hazar sediments are composed of a wider range of clay minerals, i.e. kaolinite, illite and chlorite, compared to the four experiments that only used kaolinite (Table 2). It is difficult to establish the effect of each of these controlling variables on the clay flocculation independently because they are all interrelated (Whitehouse et al., 1960; Mietta et al., 2009). A brief description is provided below of some elements of discussion that might be worth considering in future experiments on clay-rich sediment flows.

Firstly, it is well known that salinity can decrease the repulsive forces between the clay particles and therefore enhance flocculation (Whitehouse et al., 1960; Mietta et al. 2009; Pourmohammadbagher \& Shaw, 2016). However, different clay types may behave differently to salt concentration (Gorakhki \& Bareither, 2015). Secondly, several studies have shown that clay flocculation decreased with increasing pH (e.g. Whitehouse et al., 1960; Edzwald \& O’Melia, 1975; Chamley, 1989). In particular, Gupta et al. (2011) showed that kaolinite particles tended to be dispersed at $\mathrm{pH}=9$, similar to the alkaline water of Lake Hazar. Lake Hazar water could thus have decreased the flow cohesion, permitting 
turbulence to occur in the clay-rich turbidity current events studied. Thirdly, organic matter can create thin coatings on clays, thereby reducing flocculation potential (Gibbs, 1983). Between $8 \%$ and 10\% of organic matter have been measured in Lake Hazar sediments (Fig. 4) and may thus also have decreased the flow cohesion.

The effects mentioned above have mainly been measured in static, calm waters. Interaction between water chemistry and clay type has not been investigated in detail for fast-moving turbidity currents where turbulence and sediment-water mixing are suspected to have a great impact. There are some rare recent studies such as Baas et al. (2016) who compared the behaviour of bentonite to kaolinite in a new set of experiments on suspended flows. This type of investigation should be multiplied and expanded to improve current understanding of the behaviour of clay-rich turbidity currents in real settings.

\section{CONCLUSIONS}

Depositional processes at the origin of thin clayey sand turbidites found in three coring locations at Lake Hazar have been examined precisely in this study. Three conclusions may be drawn.

On the trigger of thin lacustrine turbidites and their occurrence in clusters. Turbidites found in Lake Hazar occur in vertically stacked clusters of thin event beds. Sources for these turbidites are different from one coring location to another and are inferred to correspond to surficial slope remobilisation, a process evidenced in few studies elsewhere (e.g. Moernaut et al., 2017; McHugh et al., 2016). The most likely triggering process for these slope remobilisations is earthquakes, given the strong seismic background of the basin (Ambraseys, 1989; Cetin et al., 2003). The reason for turbidites occurring in clusters is tentatively linked to the occurrence of earthquakes generated in sequences along the East-Anatolian Fault (Nalbant et al., 2002), but this remains hypothetical as a robust age model would be needed.

This article is protected by copyright. All rights reserved. 
Flow behaviour of turbidity currents is recorded in thin clayey sand lacustrine turbidites. Three types of turbidites were identified in this study. The first type is linked to laminar flows dominated by cohesion, the second type to a transitional regime where cohesion balances with turbulence and the third one to flows dominated by turbulence. The number and grain size of turbidites per cluster are higher in the proximal coring location compared to the two distal ones. Therefore flows became more dilute with distance and the frequency of deposits recorded with distance from their respective sources reduced. The three types of turbidites are found in the three coring locations, always showing a higher intensity, i.e. thicker turbidites and coarser grain size, in proximal site 1 compared to the two distal sites. Dynamics of the sediment flow evolution is thus strongly influenced by the run-out distances. Furthermore, turbidites found in Lake Hazar show that the presence of clay particles within turbidity currents leads to flocculation and flow transformation, from laminar to transitional and turbulent regimes.

Field scale turbidites as a test for flume experiments of transitional flows. Several flume experiments have shown that clay content had a key role in a sediment flow dynamics by creating cohesive forces balancing with turbulence (Amy et al., 2006; Sumner et al., 2009; Baas et al., 2011; Manica, 2012). The clay-rich event deposits of this study indeed provide evidence for the occurrence of different flow behaviours, from a cohesion-dominated regime to transitional and turbulencedominated regimes. However, while the flume experiments generally showed that turbulence was damped by cohesion for low clay content, i.e. as low as 5\% (Postma, 1986), the present study suggests that turbulence was the dominant mechanism at the origin of type 3 deposits despite their high clay fraction, i.e. $30 \%$ of the total sediment. This divergence relates to input variables such as water chemistry and clay mineralogy that are not routinely considered in experimental studies. In particular, Lake Hazar sediments contain a wider range of clay minerals, i.e. kaolinite, illite and chlorite, compared to flume studies which only used kaolinite. Furthermore, Lake Hazar water is characterised by high values of $\mathrm{pH}$ and salinity, i.e. two parameters widely known as controlling factors on clay behaviour (Whitehouse et al., 1960). These observations in a real setting allow the suggestion of new 
key controlling variables to be considered in future flume experiments on clay-rich sediment flows.

While monitoring of active turbidity currents is the most efficient approach to understand their dynamics, it remains difficult and by consequence restricted to only a few locations worldwide (Talling et al., 2015). Characterisation of turbidity currents therefore mainly relies on the observation of their deposits; the settling processes linking deposits to their parent flow being inferred by flume experiments. This combined approach has been used in this contribution, which shows that flow dynamics at the origin of lacustrine clay-rich turbidity currents can be characterised by looking at the deposits they leave behind.

\section{ACKNOWLEDGEMENTS}

This research was funded by the European Commission Marie Curie Excellence Grant Project "Understanding the irregularity of seismic cycles: A case study in Turkey" (MEXT- CT-2005025617: Seismic Cycles), hosted by the Seismology Section of the Royal Observatory of Belgium. Coring was carried out in collaboration with Istanbul Technical University, Eastern Mediterranean Centre for Oceanography and Limnology (ITU-EMCOL). The authors thank X. Boes, E. Damc1, D. Acar and C. Somuncuoğlu for their efforts during the coring mission. Many thanks to Nathalie Fagel (Dept. of Geology, Université de Liège) for core storage and XRD measurements. The authors are grateful to Philippe Martinez (Université de Bordeaux), Anne-Lise Develle and Christian Beck (EDYTEM, Université Savoie Mont Blanc) regarding XRF core scanning. Many thanks to Joshua Griffiths (University of Liverpool) for fruitful discussions on clay minerals. Associate Editor Jaco Baas and two anonymous reviewers are gratefully acknowledged for their reviews and valuable comments made on earlier versions of this paper. We particularly thank reviewer Michael Clare for his thorough reviews which substantially improved the manuscript.

This article is protected by copyright. All rights reserved. 


\section{REFERENCES}

Aksoy, E., Inceöz, M. and Koçyigit, A. (2007) Lake Hazar Basin: a negative flower structure on the East Anatolian Fault System (EAFS), SE Turquey. Turk. J. Earth Sci., 16, 319-338.

Ambraseys, N. (1989) Temporary seismic quiescence: SE Turquey. Geophys. J.+, 96, 311- 331.

Amy, L.A., Talling, P.J., Edmonds, V.O., Sumner, E.J., and Lesueur, A. (2006) An experimental investigation of sand-mud suspension settling behaviour: implications for bimodal mud contents of submarine flow deposits. Sedimentology, 53, 1411-1464.

Avşar, U., Hubert-Ferrari A., De Batist M., Schmidt S., and Fagel N. (2015) Sedimentary records of past earthquakes in Boraboy Lake during the last $c a 600$ years (North Anatolian Fault, Turkey). Palaeogeography, Palaeoclimatology, Palaeoecology, 433, 1-9.

Baas, J.H., Best, J.L., and Peakall, J. (2011) Depositional processes, bedform development and hybrid bed formation in rapidly decelerated cohesive (mud-sand) sediment flows. Sedimentology, 58, 1953-1987.

Bahri, M.A., Warnock, G., Plenevaux, A., Choquet, P., Constantinesco, A., Salmon, E., Luxen, A., and Seret, A. (2010) Performance evaluation of the General Electric eXplore CT 120 micro-CT using the vmCT phantom. Nucl. Instrum. Methods A, 648, 181-185.

Beck, C. (2009) Late Quaternary lacustrine paleo-seismic archives in north-western Alps: Examples of earthquake-origin assessment of sedimentary disturbances". Earth-Sci. Rev., 96, 327344.

Becker, A., Daverport, C.A. and Giardini, D. (2002) Palaeoseismicity studies on end-Pleistocene and Holocene lake deposits around Basle, Switzerland. Geophys. J. Int., 149, 659-678.

Bertrand, S., Charlet, F., Chapron, E., Fagel, N., and De Batist, M. (2008) Reconstruction of the Holocene seismotectonic activity of the Southern Andes from seismites recorded in Lago Icalma, Chile, $39^{\circ}$ S. Palaeogeogr. Palaeoecol. 259, 301-322.

This article is protected by copyright. All rights reserved. 
Biscaye, P.E. (1965) Mineralogy and sedimentation of recent deep-sea clay in the Atlantic Ocean and adjacent seas and oceans. Geol. Soc. Am. Bull., 76, 803-831.

Bouma, A. H. (2000). Fine-grained, mud-rich turbidite systems: model and comparison with coarsegrained, sand-rich systems. Special publication-sepm, 68, 9-20.

Carter, L., Gavey, R., Talling, P. J. and Liu, J. T. Insights into submarine geohazards from breaks in subsea telecommunication cables. Oceanography 27 (2), 58-67 (2014).

Cetin, H., Güneyli, H. and Mayer, L. (2003) Paleoseismology of the Palu-Lake Hazar segment of the East Anatolian Fault Zone, Turquey. Tectonophysics, 374, 163-197.

Chamley, H. (1989) Clay Sedimentology. Springer-Verlag, Berlin. 623 p.

Chapron, E., Ariztegui, D., Mulsow, S., Villarosa, G., Pino, M., Outes, V., Juvignié, E. and Crivelli, E. (2006) Impact of the 1960 major subduction earthquake in Northern Patagonia (Chile, Argentina). Quatern. Int., 158, 58-71.

Charles, S., Ferreol, M., Chaumot, A. and Péry, A. (2004) Food availibilty effect on population dynamics of the midge Chironomus riparius: a Leslie modeling approach. Ecol. Model., 175, 217229.

Clare, M. A., Hughes Clarke, J.E., Talling, P.J., Cartigny, M.J.B., and Pratomo, D.G. (2016) Preconditioning and triggering of offshore slope failures and turbidity currents revealed by most detailed monitoring yet at a fjord-head delta. Earth Planet. Sci. Lett. 450, 208-220.

Cohen, A. (2003) Paleolimnology: the history and evolution of lake systems. New York: Oxford University Press, 510p.

Coussot, P., Nguyen, Q.D., Huynh, H.T., and Bonn, D. (2002) Avalanche behaviour in yield stress fluids. Phys. Rev. Lett., 88, Art. 17551.

Cnudde, V. and Boone, M.N. (2013) High-resolution X-ray computed tomography in geosciences: A review of the current technology and applications. Earth-Sci. Rev., 123, 1-17.

Dittrich, M. and Obst, M. (2004) Are picoplankton responsible for calcite precipitation in lakes? 
Ambio, 33, 559-564.

Drab, L., Carlut, J, Hubert-Ferrari, A., Martinez, P, Lepoint, G. and El Ouahabi, M. (2015) Paleomagnetic and geochemical record from cores from the Sea of Marmara, Turkey: Age constraints and implications of sapropelic deposition on early diagenesis. Mar. Geol., 360, 40-54.

Edzwald, J.K. and O' Melia, C.R. (1975) Clay distributions in recent estuarine sediments. Clay Miner., 23, 39-44.

Eriş, K.K. (2012) Late Pleistocene-Holocene sedimentary records of climate and lake-level changes in Lake Hazar, eastern Anatolia, Turkey. Quat. Int. 302, 123-134.

Forsberg, C. F., Heyerdahl, H., and Solheim, A. (2016). Underwater mass movements in lake Mjøsa, Norway. In Submarine Mass Movements and their Consequences, Springer International Publishing, 191-199.

Galy, V., France-Lanord, C., Beyssac, O., Faure, P., Kudrass, H., and Palhol, F. (2007) Efficient organic carbon burial in the Bengal fan sustained by the Himalayan erosional system. Nature 450, 407-410.

Garcia Moreno, D.; Hubert-Ferrari, A.; Moernaut, J.; Fraser, J.; Boës, X.; Van Daele, M.; Avsar U., Cagatay, N. and De Batist, M. (2011) Structure and recent evolution of the Hazar basin. A strike-slip basin on the East Anatolian Fault, Eastern Turkey. Basin research, 23, 191207.

Gibbs, R. J. (1983). Effect of natural organic coatings on the coagulation of particles. Environ. Sci. Technol. 17, 237-240.

Goldfinger, C. (2011) Submarine Paleoseismology based on turbidite records. Annual Reviews of Marine Science 3, 35-66.

Goldfinger, C., Nelson, C.H., Morey, A.E., Johnson, J.R., Patton, J., Karabanov, E., GutierrezPastor, J., Eriksson, A.T., Gracia, E., Dunhill, G., Enkin, R.J., Dallimore, A. and Vallier, T. 
(2012) Turbidite event history-Methods and implications for Holocene paleoseismicity of the Cascadia subduction zone. U.S. Geol. Surv. Prof. Paper, 1661-F, 170p, available at http://pubs.usgs.gov/pp/pp1661/f

Gorakhki MH, Bareither CA. (2015). Salinity effects on sedimentation behaviour of kaolin, bentonite, and soda ash mine tailings. Appl. Clay Sci., 114, 593-602.

Gupta, V., Hampton, M., Stokes, J. R., Nguyen, A. V., and Miller, J. D. J. (2011) Particle interactions in kaolinite suspensions and corresponding aggregate structures. Colloid Interface Sci., 359, 95-103, doi: 10.1016/j.jcis.2011.03.043.

Heiri, O., Lotter, A.F., and Lemcke, G. (2001) Loss on ignition as a method for estimating organic and carbonate content in sediments: reproducibility and comparability of results. $J$. Paleolimnol., 25, 101-110.

Herece, E., 2008. Dogu Anadolu Fayi (DAF) Atlasi (Atlas of the East Anatolian Fault (EAF)). General Directorate of Mineral research and Exploration (MTA).

Hampton, M.A. (1972) Role of subaqueous debris flow in generating turbidity currents. $J$. Sediment. Petrol. 42, 775-793.

Hempton, M. R., Dunne, L. and Dewey, J. (1983) Sedimentation in an active strike-slip basin, Southeastern Turquey. J. geol. 91, 401-412.

Hempton, M. R. and Dunne, L. (1984) Sedimentation in pull-apart basins: active examples in easter Turquey. J. geol. 92, 513-530.

Hubert-Ferrari, A., Avsar, U., El Ouahabi, M., Lepoint, G., Martinez, P. and Fagel, N. (2012) Paleoseismic record obtained by coring a sag-pond along the North Anatolian Fault (Turkey). Ann. Geophys. 55 (5), 929-953.

This article is protected by copyright. All rights reserved. 
Hubert-Ferrari, A., El-Ouahabi, David Garcia-Moreno, D., Avşar, U., Altınok, S., Schmidt, S., Fagel, N., and Çağatay, N., (2017accepted). Earthquake imprints on a lacustrine deltaic system: the Kürk Delta along the East Anatolian Fault (Turkey). Accepted in Sedimentology. doi:10.1111/sed.12355

Jan Weltje, G. and Tjallingii, R. (2008) Calibration of XRF core scanners for quantitative geochemical logging of sediment cores: Theory and application. Earth Planet. Sc. Letters 274, 423-438.

Kadir, S., and Akbulut, A. (2009) Mineralogy, geochemistry and genesis of the Taşoluk kaolinite deposits in pre-Early Cambrian metamorphites and Neogene volcanites of Afyonkarahisar, Turkey. Clay Minerals, 44 (1), 89-112.

Kneller, B., and McCaffrey, W. (1999). Depositional effects of flow nonuniformity and stratification within turbidity currents approaching a bounding slope: deflection, reflection, and facies variation. Journal of Sedimentary Research, 69 (5).

Kneller, B., and Buckee, C. (2000). The structure and fluid mechanics of turbidity currents: a review of some recent studies and their geological implications. Sedimentology, 47, 62-94.

Koçer, M. A. T. and Sen, B. (2014). Some factors affecting the abundance of phytoplankton in an unproductive alkaline lake (Lake Hazar, Turkey). Turk. J. Bot. 8, 790-799.

Kuenen, P.H. and Migliorini, C.I. (1950) Turbidity currents as a cause of graded bedding. $J$. Geology, 58, 1-27.

Last, M. and Smol, J. (2002) Tracking Environmental change using lake sediments. Kluwer Academic Publisher, 516p.

Manica, R. (2012) Sediment gravity flows: study based on experimental simulations. In: Hydrodynamics - Natural Water Bodies. Ed. H. Schulz, InTech, Rijeka, Croatia, 263-286.

McBride, E. F. (1974) Significance of color in red, green, purple, olive, brown, and gray beds of 
Difunta Group, Northeastern Mexico. Journal of Sedimentary Research, 44 (3).

Marco, S., Stein, M., and Agnon, H.R. (1996) Long-term earthquake clustering: a 50,000-year paleoseismic record in the Dead-sea Graben. J. Geophys. Res., 101(B3), 6179-6191.

McHugh, C., Seeber, L., Cormier, M.-H., Dutton, J., Catagay, N., Polonia, A., Ryan W.B.F. and Gorur, N. (2006) Sub-marine earthquake geology along the North Anatolian Fault in the Marmara Sea, Turkey: A model for transform basin sedimentation. Earth Planet Sc. Lett., 248, 661-684.

Meyers, P.A. and J.L. Teranes. (2001). Sediment organic matter. In: Last, W.M., Smol, J.P. (Eds.), Tracking Environmental Changes Using Lake Sediment. Physical and geochemical methods, 2. Kluwer Academic, Dordrecht, The Netherlands, 239-270.

Middleton, G.V. (1966) Experiments on density and turbidity currents: II. Uniformflow of density currents. Canadian Journal of Earth Sciences 3, 627-637.

Middleton, G.V. (1967) Experimental studies of density and turbidity currents III, deposition of sediment: Can. J. Earth Sci., 4, 475-505.

Middleton, G.V. and Hampton, M.A. (1973) Sediment gravity flows: mechanisms of flow and deposition: In: Turbidites and Deep-Water Sedimentation, pp. 1-38. SEPM Pacific Section, Short course lecture notes.

Mietta, F., Chassagne, C., Manning, A. J., and Winterwerp, J. C. (2009). Influence of shear rate, organic matter content, $\mathrm{pH}$ and salinity on mud flocculation. Ocean Dynamics 59 (5), 751-763.

Migeon, S., Weber, O., Faugeres, J.-C. and Saint-Paul, J. (1998) Scopix: a new X-ray imaging system for core analysis. Geo-Mar. Lett. 18, 251-255.

Moernaut, J., De Batist, M., Charlet, F., Heirman, K., Chapron, E., Pino, M., Brummer, R. and Urrutia, R. (2007) Giant earthquakes in South-Central Chile revealed by Holocene masswasting events in Lake Puyehue. Sediment. Geol. 195, 239-256.

This article is protected by copyright. All rights reserved. 


\section{Moernaut, J., Van Daele, M., Heirman, K., Fontijn, K., Strasser, M., Pino, M., Urrutia,}

R. and De Batist, M. (2014) Lacustrine turbidites as a tool for quantitative earthquake reconstruction: New evidence for a variable rupture mode in south central Chile. J. Geophys. Res.Sol. Ea., 119, 1607-1633. doi: 10.1002/2013JB010738

Moernaut, J., Van Daele, M., Strasser, M., Clare, M.A., Heirman, K., Viel, M., Cardenas, J., Kilian, R., Ladron de Guevara, B., Pino, M., Urrutia, R. and De Batist, M. (2017). Lacustrine turbidites produced by surficial slope sediment remobilization: A mechanism for continuous and sensitive turbidite paleoseismic records. Mar. Geol., in press, 2017. http://dx.doi.org/10.1016/j.margeo.2015.10.009.

Monecke, K., Anselmetti, F.S., Becker, A., Schnellmann, M., Sturm, M. and Giardini, D. (2006) Earthquake-induced deformation structures in lake deposits: A Late Pleistocene to Holocene paleoseismic record for Central Switzerland. Eclogae geol. Helv. 99, 343-362.

Moore, D. M. and Reynolds, R. C. (1997) X-Ray Diffraction and the Identification and Analysis of Clay Minerals. Oxford, Oxford University Press.

Nalbant, S.S., McCloskey J.S., and Barka, A. A. (2002) Stress accumulation and increased seismic risk in eastern Turkey. Earth Planet Sc. Lett. 195, 291-298.

Nilsen, T.H., Shew, R.D., Steffens, G.S. and Studlick, J.R.J. (2008) Atlas of deep-water outcrops. Boulder CO, USA, AAPG and Shell Exploration \& Production. AAPG Studies in Geology, 66.

Obermeier (2009) Using liquefaction-induced and other soft-sediment features for paleoseismic analysis. In McCalpin (2009). Paleosismology, International geophysics series 95, 497-564.

Parker, G. (1982) Conditions for the ignition of catastrophically erosive turbidity currents. Mar. Geol., 46, 307-327.

Piper, D.J.W. (1978) Turbidite muds and silts on deep sea fans and abyssal plains. In: Stanley and Kelling. Sedimentation in submarine canyons, fans and trenches. Dowden, Hutchisson and Ross, Stroudsburg, Pennsylvania, 163-176.

This article is protected by copyright. All rights reserved. 
Piper, D. J. W. \& Normark, W. R. (2009) Processes that initiate turbidity currents and their influence on turbidites: a marine geology perspective. J. Sediment. Res. 79, 347-362.

Postma, G. (1986) Classification for sediment gravity-flow deposits based on flow conditions during sedimentation. Geology 144, 291-294.

Pourmohammadbagher A and Shaw J. M. (2016) Probing the Role of Water Chemistry on the Behavior of Clays in Process and Natural Environments Using Solution Calorimetry. Energy \& Fuels 30 (7), 5964-5969.

Sen, B., Koçer, M.A.T. and Alp, M.T. (2002) Physical and chemical properties of rivers drained into Lake Hazar. J. Eng. Sci, 14, 241-248.

Shephard F.P. (1954). Nomenclature based on sand-silt-clay ratios. J. Paleolim. 23: 141-164. Sed. Pet. 24: $151-158$.

Stevenson, C.J., Talling, P.J., Masson, D.G., Sumner, E.J., Frenz, M. and Wynn, R.B. (2014) The spatial and temporal distribution of grain-size breaks in turbidites. Sedimentology 61, $1120-1156$.

Strasser, M., Anselmetti, F.S., Fäh, D., Giardini, D. and Schnellmann, M. (2006). Magnitudes and source areas of large prehistoric northern Alpine earthquakes revealed by slope failures in lakes. Geology 34, 1005-1008. doi: 10.1130/G22784A.1

Strasser, M.; Monecke, K.; Schnellmann, M. and Anselmetti, F. (2013). Lake sediments as natural seismographs: A compiled record of Late Quaternary earthquakes in Central Switzerland and its implication for Alpine deformation. Sedimentology 60, 319-341. doi: 10.1111/sed.12003

Sumner, E.J., Amy, L.A., and Talling, P.J. (2008) Deposit structure and processes of sand deposition from decelerating sediment suspensions. J. Sediment. Res.78, 529-547.

Sumner, E.J., Talling, P. J., and Amy, L.A. (2009) Deposits of flows transitional between turbidity current and debris flow. The Geological Society of America - Geology 37 (11), 991 - 994.

Stow, D. A. V. and Bowen, A. J. (1978) Origin of lamination in deep sea, fine-grained sediments. 
Nature, 274, 324-328.

Stow, D. A. V. and Bowen, A. J. (1980) A physical model for the transport and sorting of finegrained sediment by turbidity currents. Sedimentology 27 (1), 31-46.

Talling, P.J., Masson, D.G., Sumner, E.J., and Malgesini, G. (2012) Subaqueous sediment density flows: depositional processes and deposit types. Sedimentology 59, 1937-2003.

Talling, P.J, Paull, C.K., and Piper, D.J.W. (2013) How are subaqueous sediment density flows triggered, what is their internal structure and does it evolve? Direct observations from monitoring of active flows. Earth Sci. Rev., 125, 244-287.

Talling, P.J. (2014) On the triggers, resulting flow types and frequencies of subaqueous sediment density flows in different settings. Mar. Geol. 352, 155-182.

Thorez, J. (1976) Practical identification of clay minerals. Liège, G. Lelotte, p.90.

Timm, T., Arslan, N., Rüzgar, M., Martinsson, S. and Erseus C. (2013) Oligochaeta (Annelida) of the profundal of Lake Hazar (Turquey), with description of Potamothrix alatus hazaricus n. ssp. Zootaxa 3716, 144-156.

Tonbul, S. and Yiğit, A., (1995) Pleyistosen'den Günümüze Hazar Gölü'ndeki Seviye Değişmeleri, Çevresel Etkileri ve Hatunköy Kapması, 1. Hazar Gölü ve Çevresi Sempozyumu, Sivrice-Elazı̆g., $41-69$.

Uhlmann, D. and Horn, W. (2001) Hydrologie der Binnengewässer. Ulmer, Stuttgart, Germany.

Van Daele, M., Moernaut, J., Silversmit, G., Schmidt, S., Fontijn, K., Heirman, K., Vandoorne, W., De Clercq, M., Van Acker, J., Wolff, C., Pino, M., Urrutia, R., Roberts, S.J., Vincze, L. and De Batist, M. (2014a) The 600 yr eruptive history of Villarrica Volcano (Chile) revealed by annually laminated lake sediments. Geol. Soc. Am. Bull. 126, 481-498.

Van Daele, M., Cnudde, V., Duyck, P., Pino, M., Urrutia, R. and De Batist, M. (2014b) Multidirectional, synchronously-triggered seismo-turbidites and debrites revealed by X-ray computed tomography (CT). Sedimentology 61, 861-880.

This article is protected by copyright. All rights reserved. 
Van Daele M., Moernaut, J., Doom, L., Boes, E., Fontijn, K., Heirman, K., Vandoorme, W., Hebbel, D., Pino, M., Urrutia, R., Brümmer, R. and De Batist, M. (2015) A comparison of the sedimentary records of the 1960 and 2010 great Chilean earthquakes in 17 lakes: Implications for quantitative lacustrine palaeoseismology. Sedimentology, 62, 1466-1496, doi: 10.1111/sed.12193.

Waldmann, N., Anselmetti, F.S., Ariztegui, D., Austin, J.A., Jr., Pirouz, M., Moy, C.M. and Dunbar, R. (2011) Holocene mass-wasting events in Lago Fagnano, Tierra del Fuego (54 degrees S): implications for paleoseismicity of the Magallanes-Fagnano transform fault. Basin Res. 23, $171-190$.

Whitehouse U.G., Jeffrey L.M. and Debbrecht J.D. (1960) Differential settling tendencies of clay mineral in saline water, 7th Nat. Conf. Clays and Clay Minerals, 1-79.

Yiğit, A. (1995) "Hazar Gölü Suları Altında Kalan Gölcük Köyü Hakkında Bir Tarihi Coğrafya Araştırması". 1. Hazar Gölü ve Çevresi Sempozyumu, Sivrice-Elazığ., 185-188.

Ziegler, M., Jilbert, T., de Lange, G. J., Lourens, L. J., and Reichart, G. J. (2008). Bromine counts from XRF scanning as an estimate of the marine organic carbon content of sediment cores. Geochemistry, Geophysics, Geosystems, 9 (5).

This article is protected by copyright. All rights reserved. 


\section{Figure Captions}

Figure 1: Top-left: Location of Lake Hazar (HL) on the East-Anatolian Fault (EAF) between the Arabia and the Anatolia plates. UTM coordinates in degrees. The rest of the figure shows the Lake Hazar Basin and its geomorphological units, the location of the three study coring sites and the fault system mapped from the seismic survey crossing the lake. MF: Master Fault; NF: Northern Fault; SF: Southern Fault; NwS: North-west Segment.

Figure 2: Top-left: Distribution of the seismic lines used in this study. The rest of the figure shows the slopes characterising the western shallow basin of Lake Hazar. Coring locations and location of the seismic reflection profiles shown in Fig. 3 are indicated.

Figure 3: Five out of a dense grid of seismic reflection profiles acquired in Lake Hazar. Coring locations are indicated on the profiles. Vertical scales are based on an acoustic velocity of $1600 \mathrm{~m} / \mathrm{s}$ for soft sediments (Garcia Moreno et al., 2010). TWT: two-way-travel time; Pr: Promontory; SF: Southern Fault; MF: Master Fault; DB: Deep Basin.

Figure 4: Comparison of parameters measured on short cores taken from the three study sites. Schematic logs: drawn on a visual basis of the core surface; Grey levels: extracted from the X-ray radiographs; $\mathrm{Ca} / \mathrm{Al}$ : Ratio between Calcium and Aluminium based on XRF elemental counts; $\mathrm{Br}$ : Area of Bromine, used as a proxy of the organic content; wt $\%$ carbonates: percentage of carbonates calculated by loss on ignition; \%O.M.: percentage of organic matter calculated by loss on ignition. A ${ }^{14} \mathrm{C}$ dating was made on a short core of site 1 (95 cm depth) on organic debris sampled in the background sediments and gave a calibrated age range of 1243 to 1284 cal AD (92\% probability) using the OxCal program.

Figure 5: Measurements made on short and long cores from site 1. MS: Magnetic susceptibility (no unit); Density: density of the sediments (in grams per cubic centimetre); \%mud, silt, sand: percentage of each particle size of the total volume present in each sample taken from the cores; Mineralogy by XRD: mineralogy quantified by X-ray diffraction showing the percentage of clay 
minerals and kaolinite compared to the total mineral composition; $\mathrm{Fe} / \mathrm{Ca}$ : ratio between Iron and Calcium; Ti/Ca: ratio between Titanium and Calcium.

Figure 6: Measurements made on short and long cores from sites 2 and 3. MS: Magnetic susceptibility (no unit); Density: density of the sediments (in grams per cubic centimetre); \%mud, silt, sand: percentage of each particle size of the total volume present in each sample taken from the cores; Mineralogy by XRD: mineralogy quantified by X-ray diffraction showing the percentage of clay minerals and kaolinite compared to the total mineral composition; $\mathrm{Fe} / \mathrm{Ca}$ : ratio between Iron and Calcium; Ti/Ca: ratio between Titanium and Calcium.

Figure 7: Detailed imagery of the deposits found in the event set B of sites 1 and 2. This event set is composed of four turbidites within site 1 and two turbidites within site 2 (that are similar in site 3). CT scan images were acquired on the short cores whereas X-ray radiographs and thin sections photographs are issued from the long cores.

Figure 8: Detailed imagery of the deposits found in the event set $\mathrm{C}$ of sites 1 and 3. This event set is composed of eight turbidites named $\mathrm{C} 1$ to $\mathrm{C} 8$ within site 1 . CT scan images were acquired on the short cores whereas X-ray radiographs and thin sections photographs are issued from the long cores.

Figure 9: Detailed imagery of the deposits found in the event set D of site 1. This event set is composed of two turbidites named D1 and D2 that are both correlated with events found in sites 1 and 3. Detailed mineralogy of clay has been measured by X-ray diffraction (XRD) on three samples taken in and around turbidite D1 $(203 \mathrm{~cm}, 205 \mathrm{~cm}$ and $207 \mathrm{~cm}$ depth; see Graphs on the left). X-ray radiographs and thin sections photographs are issued from the long cores.

Figure 10: Detailed imagery of the deposits found in the event set D of sites 2 and 3. This event set is composed of two turbidites named D1 and D2 that are both correlated with events found in site 1. CT scan images were acquired on the short cores whereas X-ray radiographs and thin sections photographs are issued from the long cores.

This article is protected by copyright. All rights reserved. 
Figure 11: Map showing the distribution of the three types of turbidites found in the three sites studied at Lake Hazar.

Table 1: a. Isotope measurements made on a short core issued from site 2. b. Mineralogical measurements made on short cores taken from sites 1 and 2 .

Table 2: Comparison of the input materials employed in the four flume experiments used in the interpretation of this research.

Table 3: Sketches, characteristics and interpretation of the three main types of turbidites found in the sedimentary record of Lake Hazar.

\begin{tabular}{|c|c|c|c|}
\hline \multicolumn{4}{|c|}{ a. Isotope Measurements in Site 2} \\
\hline & & $\delta^{13} \mathrm{C} \%$ & $\mathrm{C} / \mathrm{N}$ \\
\hline \multicolumn{2}{|r|}{$\begin{array}{c}\text { Background Sediment } \\
10 \text { samples between } 44-117 \mathrm{~cm}\end{array}$} & $-25.5 \pm 0.2$ & 8.6 \\
\hline \multirow{5}{*}{ 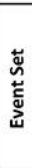 } & B $-57.0 \mathrm{~cm}$ & -25.2 & 7.9 \\
\hline & $C-57.0 \mathrm{~cm}$ & -25.6 & 8.9 \\
\hline & $\mathrm{D}-104.0 \mathrm{~cm}$ & -25.7 & 8.4 \\
\hline & $\mathrm{D}-107.5 \mathrm{~cm}$ & -25.5 & 7.9 \\
\hline & $D-109.5 \mathrm{~cm}$ & -25.4 & 7.1 \\
\hline
\end{tabular}

\begin{tabular}{|c|c|c|c|c|c|c|c|c|c|c|c|c|c|}
\hline \multicolumn{14}{|c|}{ b. Total Mineralogy by X-Ray Diffraction in Sites 1 and 2} \\
\hline & & & Quartz & Calcite & Total clay & Kaolinite & K-Feldspar & Plagioclase & Hematite & Dolomite & Muscovite & Aragonite & Pyrite \\
\hline \multirow{5}{*}{ 岌 } & \multicolumn{2}{|c|}{ Background Sediment } & $8 \pm 1 \%$ & $2 \pm 1 \%$ & $30 \pm 6 \%$ & $6 \pm 2 \%$ & $15 \pm 5 \%$ & $4 \pm 2 \%$ & $5 \pm 1 \%$ & $1 \pm 1 \%$ & $11 \pm 3 \%$ & $17 \pm 5 \%$ & $1 \pm 1 \%$ \\
\hline & \multirow{4}{*}{ 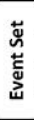 } & $\mathrm{B}-53.0 \mathrm{~cm}$ & $9 \%$ & $0 \%$ & $22 \%$ & $5 \%$ & $23 \%$ & $2 \%$ & $8 \%$ & $3 \%$ & $12 \%$ & $14 \%$ & $2 \%$ \\
\hline & & $\mathrm{C}-71.0 \mathrm{~cm}$ & $11 \%$ & $2 \%$ & $20 \%$ & $6 \%$ & $24 \%$ & $2 \%$ & $6 \%$ & $1 \%$ & $11 \%$ & $16 \%$ & $1 \%$ \\
\hline & & $D-98.5 \mathrm{~cm}$ & $9 \%$ & $3 \%$ & $20 \%$ & $4 \%$ & $14 \%$ & $6 \%$ & $8 \%$ & $1 \%$ & $10 \%$ & $24 \%$ & $1 \%$ \\
\hline & & $\mathrm{D}-102.5 \mathrm{~cm}$ & $9 \%$ & $4 \%$ & $31 \%$ & $5 \%$ & $18 \%$ & $5 \%$ & $6 \%$ & $2 \%$ & $9 \%$ & $10 \%$ & $1 \%$ \\
\hline \multirow{6}{*}{ 点 } & $\mathrm{Bac}$ & kground Sediment & $8 \pm 2 \%$ & $2 \pm 1 \%$ & $40 \pm 7 \%$ & $7 \pm 2 \%$ & $7 \pm 2 \%$ & $9 \pm 3 \%$ & $6 \pm 2 \%$ & $2 \pm 1 \%$ & $20 \pm 6 \%$ & $0 \%$ & $0 \%$ \\
\hline & \multirow{5}{*}{ 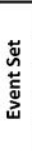 } & $\mathrm{B}-57.0 \mathrm{~cm}$ & $11 \%$ & $1 \%$ & $40 \%$ & $7 \%$ & $6 \%$ & $12 \%$ & $0 \%$ & $2 \%$ & $20 \%$ & $0 \%$ & $0 \%$ \\
\hline & & $\mathrm{c}-79.0 \mathrm{~cm}$ & $8 \%$ & $2 \%$ & $50 \%$ & $5 \%$ & $5 \%$ & $8 \%$ & $4 \%$ & $3 \%$ & $14 \%$ & $0 \%$ & $0 \%$ \\
\hline & & $D-104.0 \mathrm{~cm}$ & $10 \%$ & $1 \%$ & $32 \%$ & $8 \%$ & $6 \%$ & $18 \%$ & $4 \%$ & $3 \%$ & $19 \%$ & $0 \%$ & $0 \%$ \\
\hline & & $\mathrm{D}-107.5 \mathrm{~cm}$ & $10 \%$ & $0 \%$ & $48 \%$ & $7 \%$ & $7 \%$ & $16 \%$ & $0 \%$ & $2 \%$ & $10 \%$ & $0 \%$ & $0 \%$ \\
\hline & & $\mathrm{D}-109.5 \mathrm{~cm}$ & $10 \%$ & $0 \%$ & $43 \%$ & $7 \%$ & $4 \%$ & $10 \%$ & $7 \%$ & $2 \%$ & $17 \%$ & $0 \%$ & $0 \%$ \\
\hline
\end{tabular}

This article is protected by copyright. All rights reserved. 


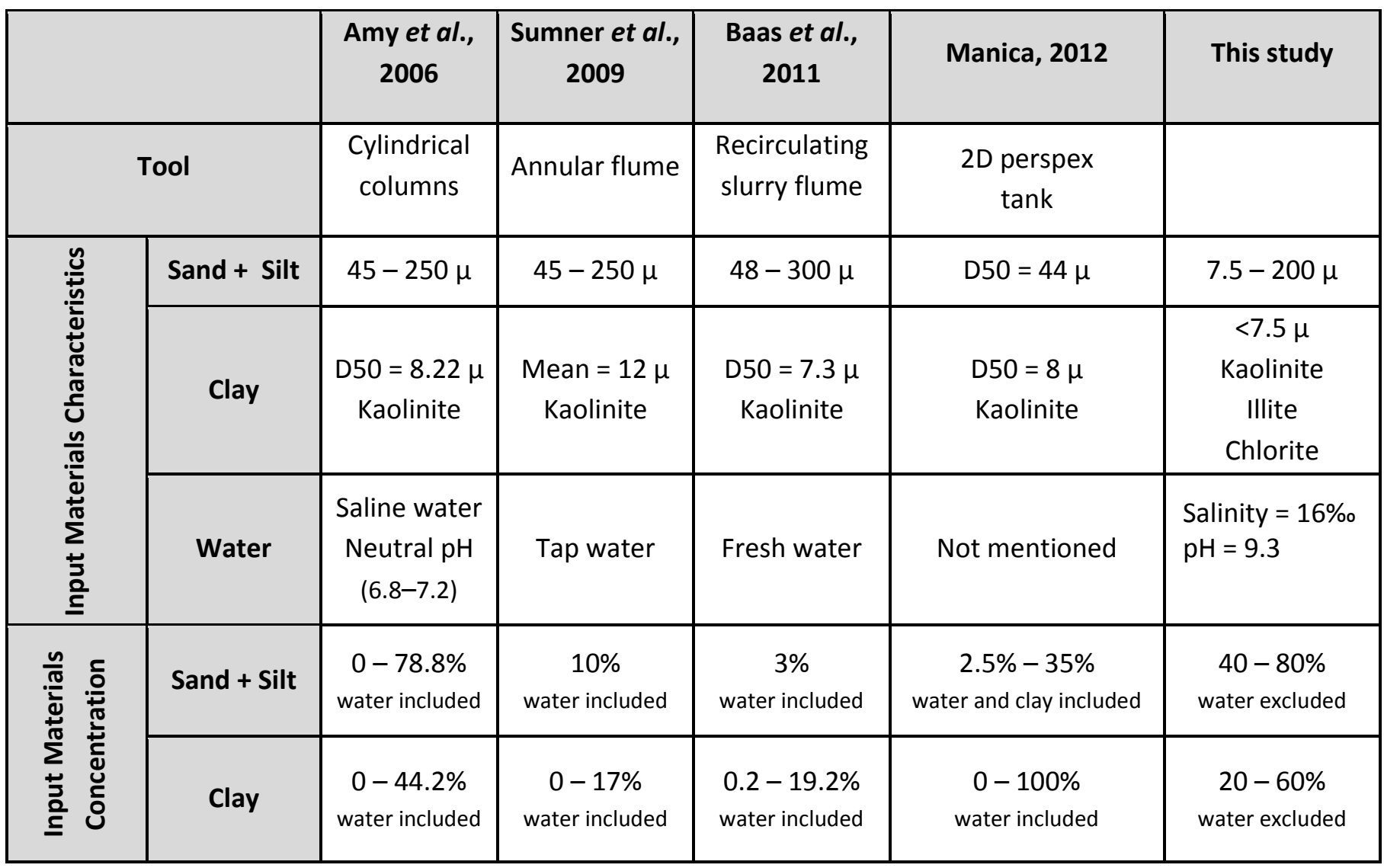

This article is protected by copyright. All rights reserved. 


\begin{tabular}{|l|l|l|l|l|l|}
\hline a. & $\begin{array}{l}\text { Type V of Amy } \\
\text { et al., 2006 }\end{array}$ & $\begin{array}{l}\text { Type IV of Sumner } \\
\text { et al., 2009 }\end{array}$ & $\begin{array}{l}\text { Quasi Laminar Plug } \\
\text { Flow deposits of } \\
\text { Baas et al., 2011 }\end{array}$ & $\begin{array}{l}\text { Region V and VI } \\
\text { deposits of } \\
\text { Manica, 2012 }\end{array}$ & Type 1 of this study \\
\hline $\begin{array}{l}\text { Characteristics } \\
\text { of the deposit }\end{array}$ & $\begin{array}{l}\text { Ungraded beds of } \\
\text { muddy sand }\end{array}$ & $\begin{array}{l}\text { Ungraded muddy sand } \\
\text { layer overlain by a mud } \\
\text { cap }\end{array}$ & $\begin{array}{l}\text { Layer made of sand, sitt } \\
\text { and clay without grading }\end{array}$ & $\begin{array}{l}\text { Ungraded clayey } \\
\text { deposits }\end{array}$ & $\begin{array}{l}\text { Ungraded clayey silt layer sometimes } \\
\text { overlain by a mud cap }\end{array}$ \\
\hline $\begin{array}{l}\text { Parent flow and } \\
\text { Settling process }\end{array}$ & $\begin{array}{l}\text { Settling by consolidation } \\
\text { and inhibited segregation }\end{array}$ & $\begin{array}{l}\text { Consolidation of a high } \\
\text { yield strength muddy } \\
\text { suspension }\end{array}$ & $\begin{array}{l}\text { Flow made of a anesive matrix able to } \\
\text { support all particles } \\
\text { sizes }\end{array}$ & $\begin{array}{l}\text { Non-Newtonian plug } \\
\text { like flow dominated by } \\
\text { cohesive forces. } \\
\text { Settling by freezing of } \\
\text { all particles sizes }\end{array}$ & $\begin{array}{l}\text { by cohesive forces } \\
\text { bn-masse settling }\end{array}$ \\
\hline
\end{tabular}

\begin{tabular}{|c|l|l|l|l|l|}
\hline b. & $\begin{array}{l}\text { Type II of Amy } \\
\text { et al., 2006 }\end{array}$ & $\begin{array}{l}\text { Type III of Sumner } \\
\text { et al., 2009 }\end{array}$ & $\begin{array}{l}\text { Upper Transitional } \\
\text { Plug Flow deposits } \\
\text { of Baas et al., 2011 }\end{array}$ & $\begin{array}{l}\text { Region II } \\
\text { deposits of } \\
\text { Manica, 2012 }\end{array}$ & Type 2 of this study \\
\hline $\begin{array}{l}\text { Characteristics } \\
\text { of the deposit }\end{array}$ & $\begin{array}{l}\text { Partially graded bed } \\
\text { of sand }\end{array}$ & $\begin{array}{l}\text { Structureless sand } \\
\text { overlain by ungraded } \\
\text { muddy sand and a } \\
\text { mud cap. }\end{array}$ & $\begin{array}{l}\text { Sandy layer overlain by } \\
\text { a muddy layer }\end{array}$ & $\begin{array}{l}\text { Partially graded bed } \\
\text { made of sand at the } \\
\text { bottom and fining } \\
\text { upwards particles on } \\
\text { the top. }\end{array}$ & $\begin{array}{l}\text { Partially graded clayey sand } \\
\text { overlain by a mud cap }\end{array}$ \\
\hline $\begin{array}{l}\text { Parent flow and } \\
\text { Settling process }\end{array}$ & $\begin{array}{l}\text { Suppression of size } \\
\text { sorting during the early } \\
\text { stages of deposition }\end{array}$ & $\begin{array}{l}\text { Transitional flow or } \\
\text { intermediate yield } \\
\text { strength muddy } \\
\text { suspension. } \\
\text { Settling by aggradation } \\
\text { or late-stage settling of } \\
\text { sand from the muddy } \\
\text { suspension. }\end{array}$ & $\begin{array}{l}\text { Flow characterised by } \\
\text { increasing cohesive } \\
\text { forces. }\end{array}$ & $\begin{array}{l}\text { Non-Newtonian plug- } \\
\text { like flow dominated by } \\
\text { cohesive forces. } \\
\text { Settling by freezing of } \\
\text { all particles sizes }\end{array}$ & $\begin{array}{l}\text { Thansitional flow characterised by } \\
\text { a balance between cohesion and } \\
\text { turbulence } \\
\text { a Gradual aggradation and } \\
\text { En-masse settling }\end{array}$ \\
\hline
\end{tabular}

\begin{tabular}{|c|c|c|c|c|c|}
\hline c. & $\begin{array}{l}\text { Type I of Amy } \\
\text { et al., } 2006\end{array}$ & $\begin{array}{l}\text { Type I of Sumner } \\
\text { et al., } 2009\end{array}$ & $\begin{array}{l}\text { Lower Transitional } \\
\text { Plug Flow deposits } \\
\text { of Baas et al., } 2011\end{array}$ & $\begin{array}{l}\text { Region I } \\
\text { deposits of } \\
\text { Manica, } 2012\end{array}$ & Type 3 of this study \\
\hline $\begin{array}{l}\text { Characteristics } \\
\text { of the deposit }\end{array}$ & $\begin{array}{l}\text { Graded beds of sand in } \\
\text { which mud content } \\
\text { increases upwards }\end{array}$ & $\begin{array}{l}\text { Structured sand } \\
\text { characterised by ripple } \\
\text { laminae andoverlainby } \\
\text { a mud cap }\end{array}$ & $\begin{array}{l}\text { Basal sand layer } \\
\text { showing lamination } \\
\text { (due to ripple bedforms } \\
\text { development) and } \\
\text { overlain by a muddy } \\
\text { layer }\end{array}$ & $\begin{array}{l}\text { Graded bed made of } \\
\text { sand }\end{array}$ & \\
\hline $\begin{array}{l}\text { Parent flow and } \\
\text { Settling process }\end{array}$ & $\begin{array}{l}\text { Incremental deposition } \\
\text { from a suspension } \\
\text { made of sand and mud } \\
\text { characterised by a } \\
\text { turbulent regime at the } \\
\text { bed interface }\end{array}$ & $\begin{array}{l}\text { Turbulent flow followed } \\
\text { by gradual aggradation } \\
\text { and reworking of the } \\
\text { bed, forming ripple } \\
\text { bedforms laminae in } \\
\text { the deposits }\end{array}$ & $\begin{array}{l}\text { Stratified flow in which } \\
\text { the base is turbulent and } \\
\text { the upper part has a } \\
\text { increasing yield strength. } \\
\text { Bed reworking occurs } \\
\text { during late stages }\end{array}$ & $\begin{array}{l}\text { Newtonian turbulent } \\
\text { flow followed by a } \\
\text { grain-to-grain settling } \\
\text { mechanism as the flow } \\
\text { decelerates }\end{array}$ & $\begin{array}{l}\text { Glow dominated by turbulence } \\
\text { G Gradual aggradation }\end{array}$ \\
\hline
\end{tabular}

This article is protected by copyright. All rights reserved. 


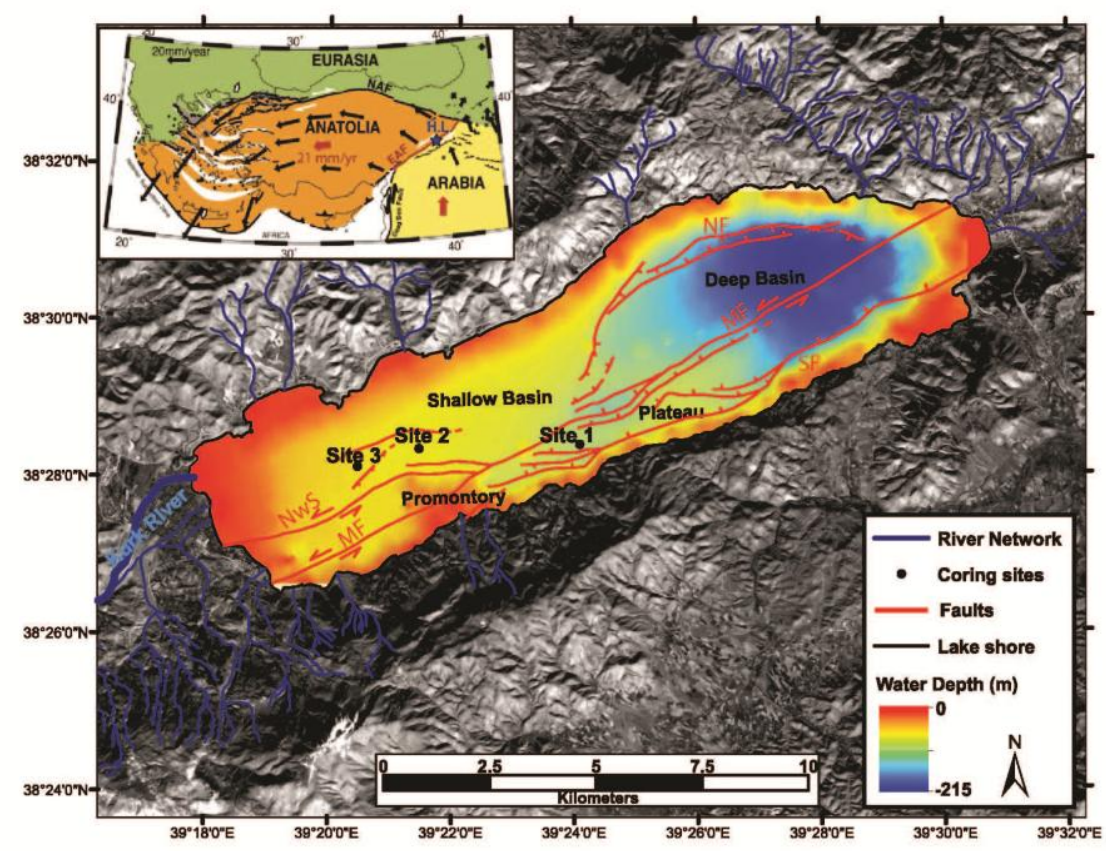

This article is protected by copyright. All rights reserved. 


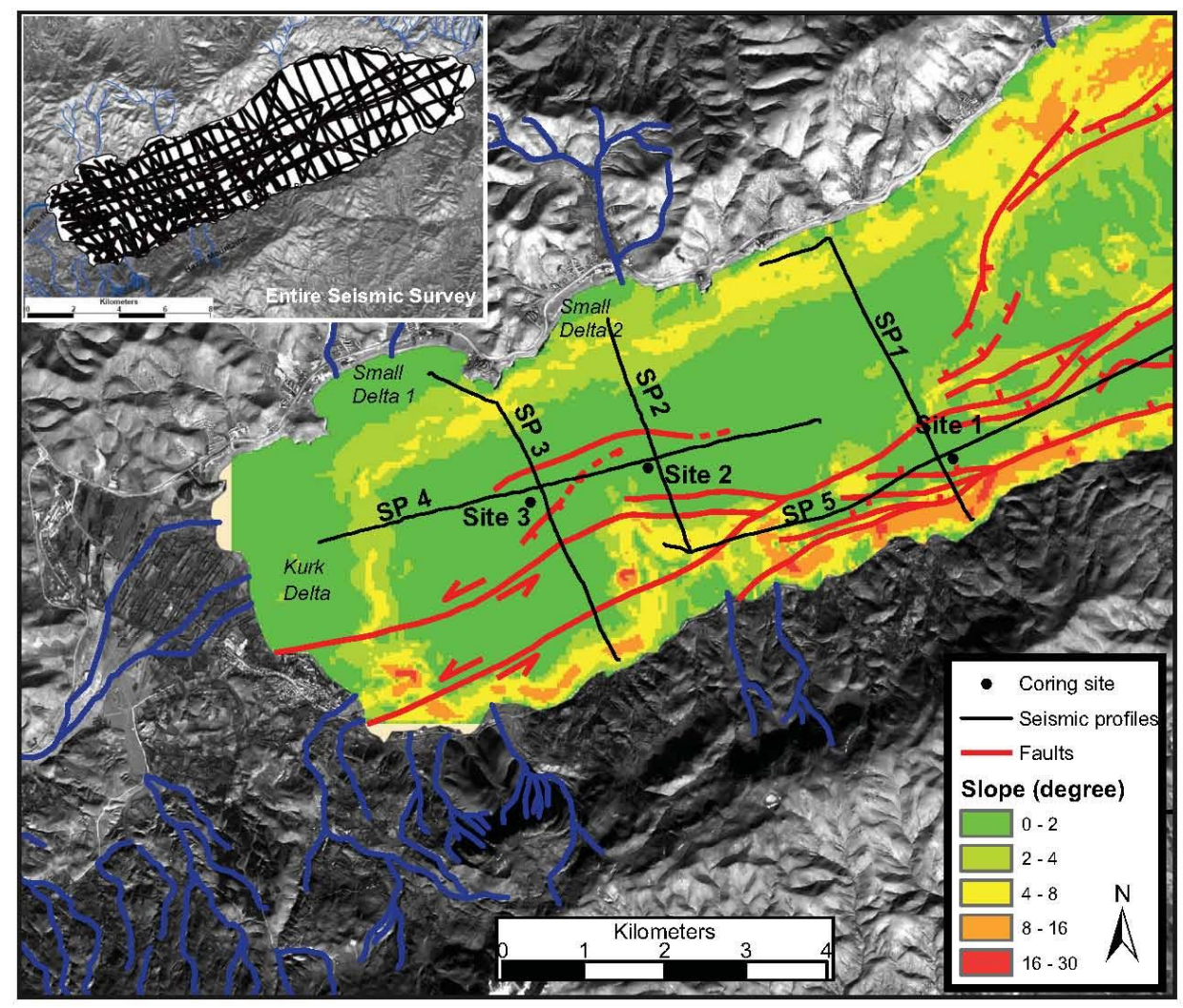

This article is protected by copyright. All rights reserved. 

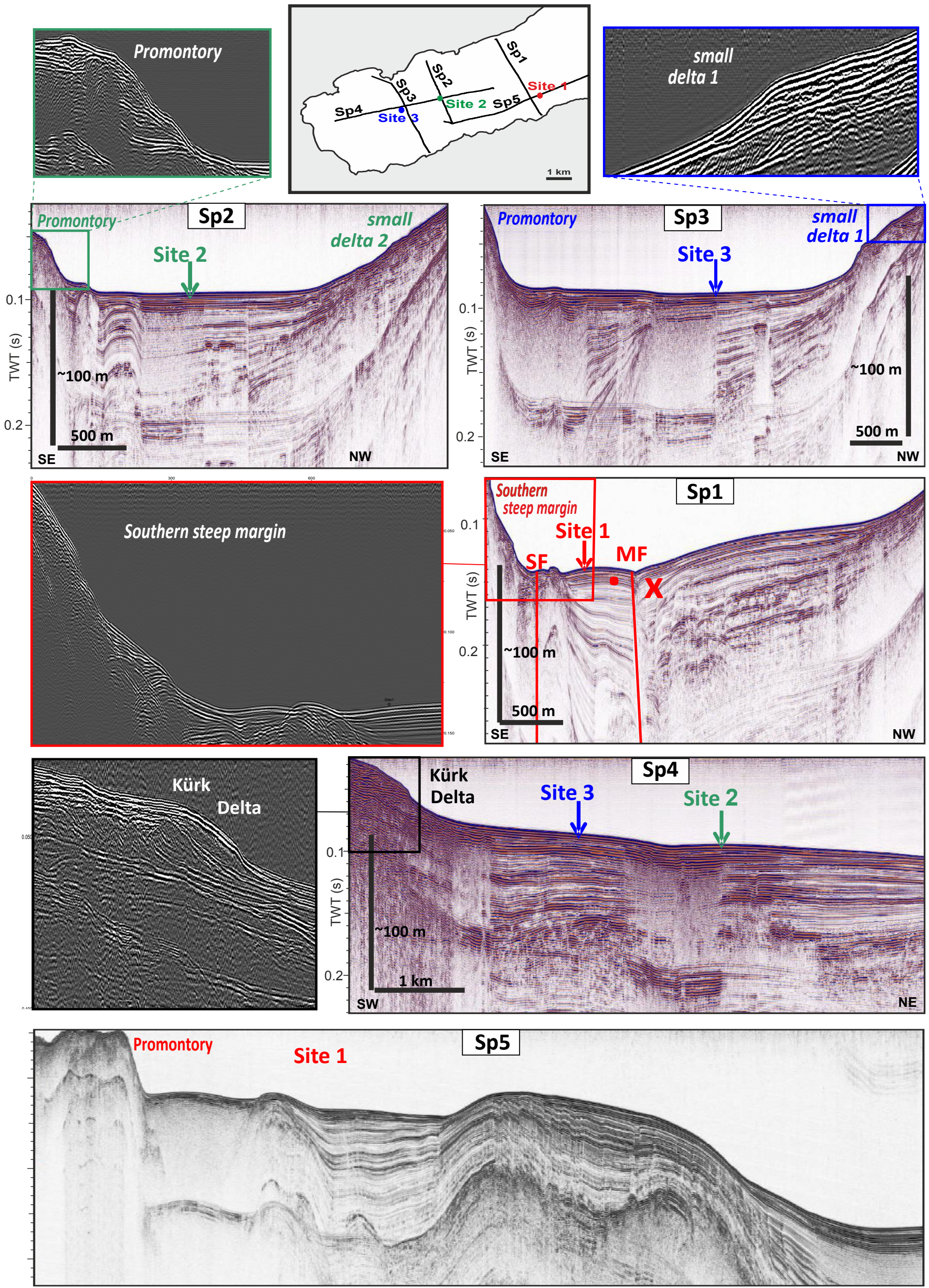

This article is protected by copyright. All rights reserved. 


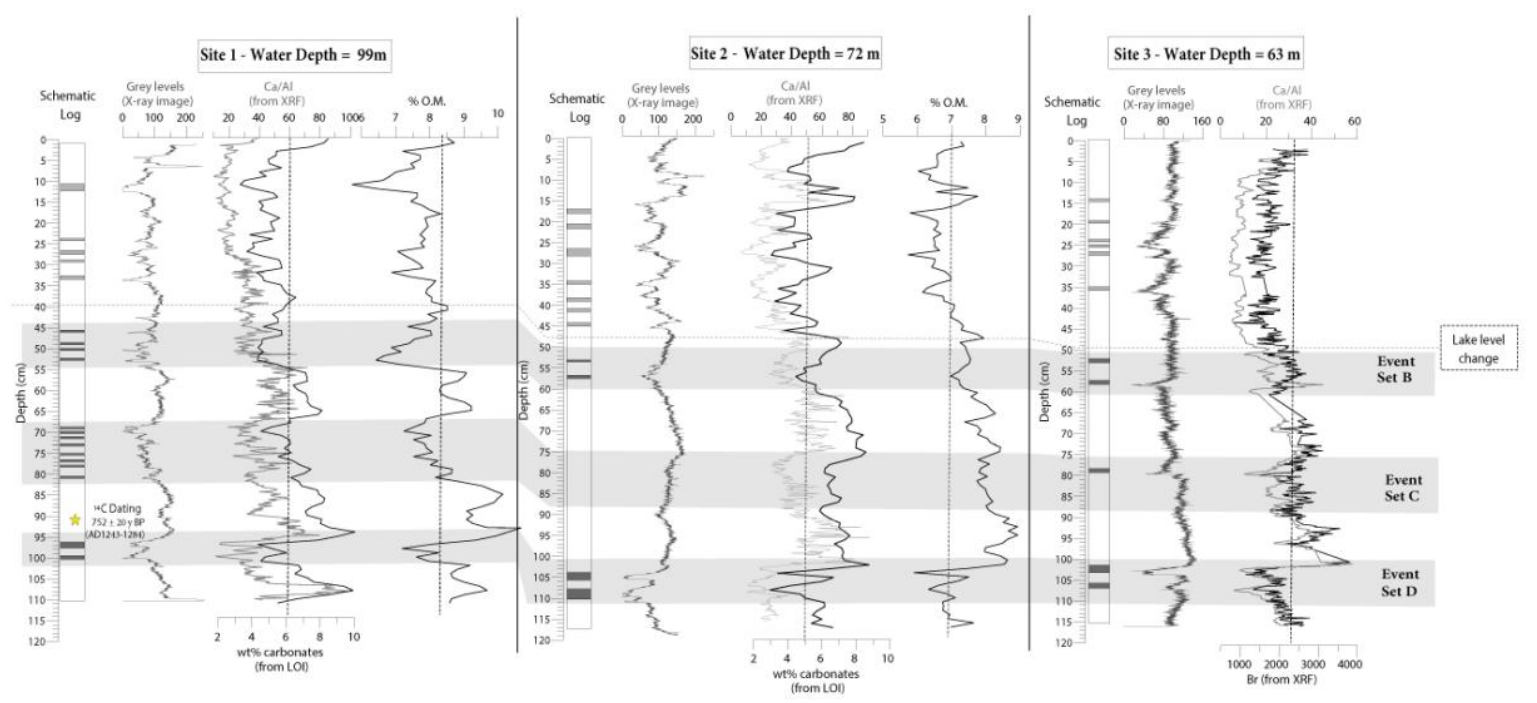

This article is protected by copyright. All rights reserved. 


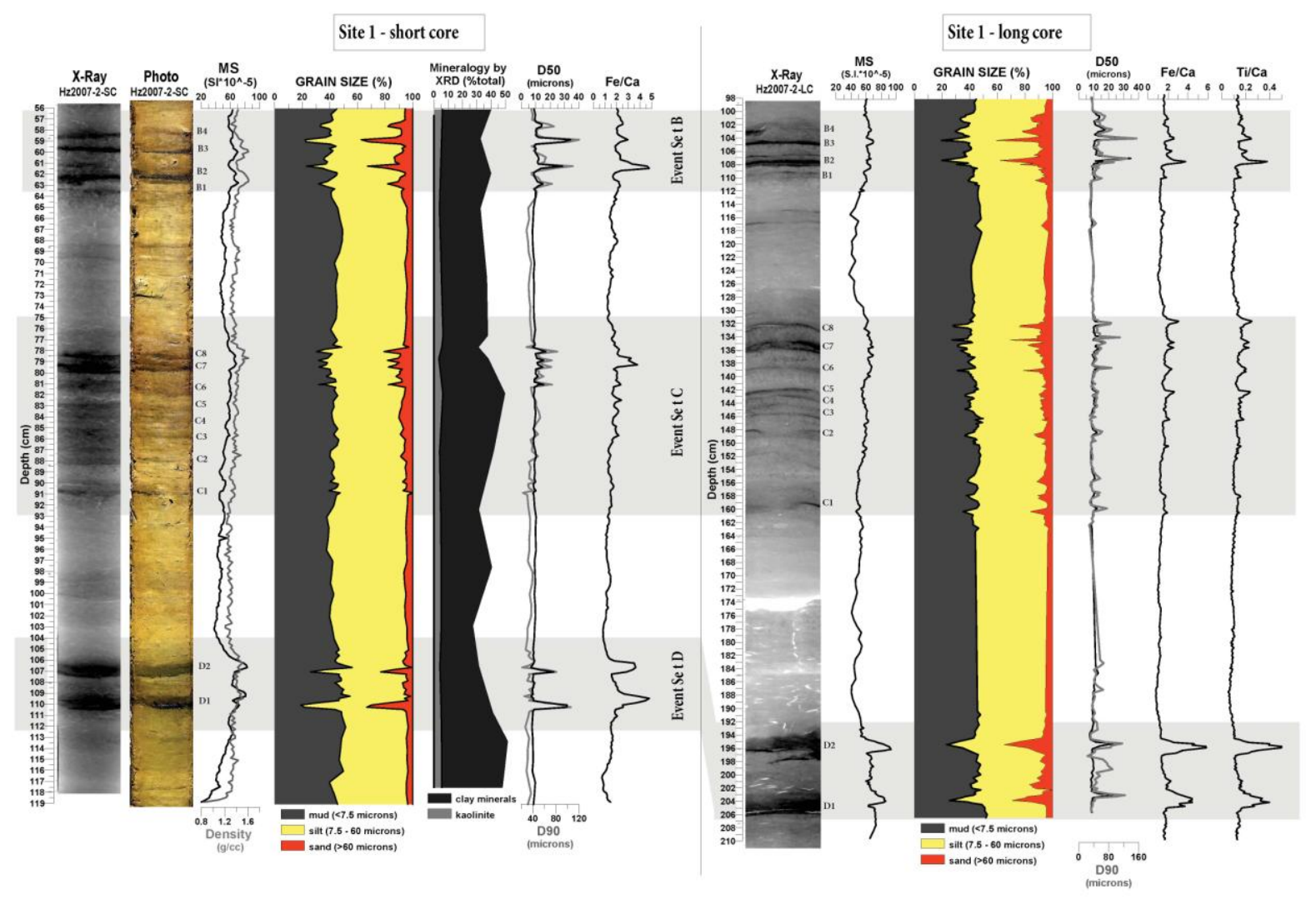

This article is protected by copyright. All rights reserved. 

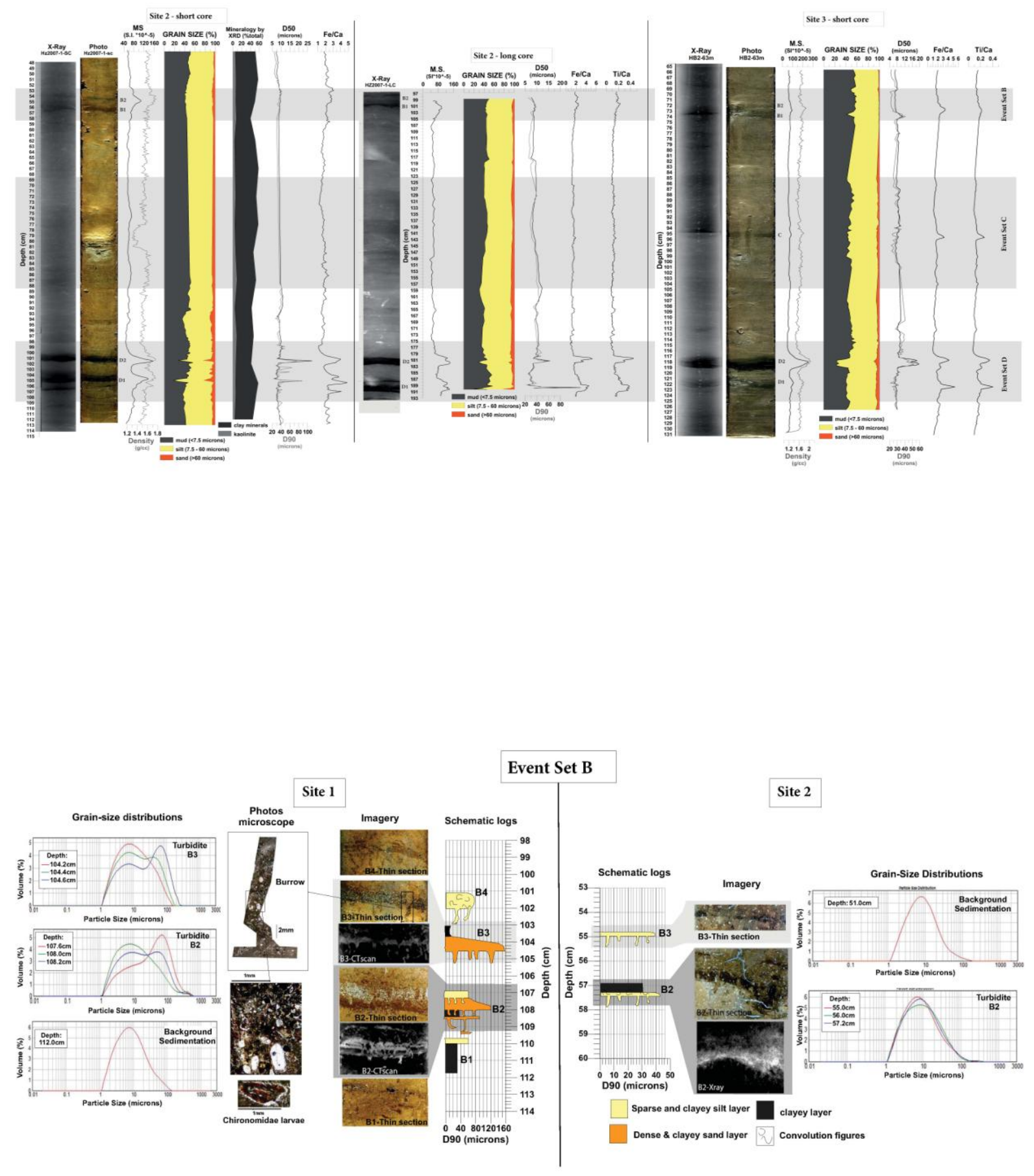

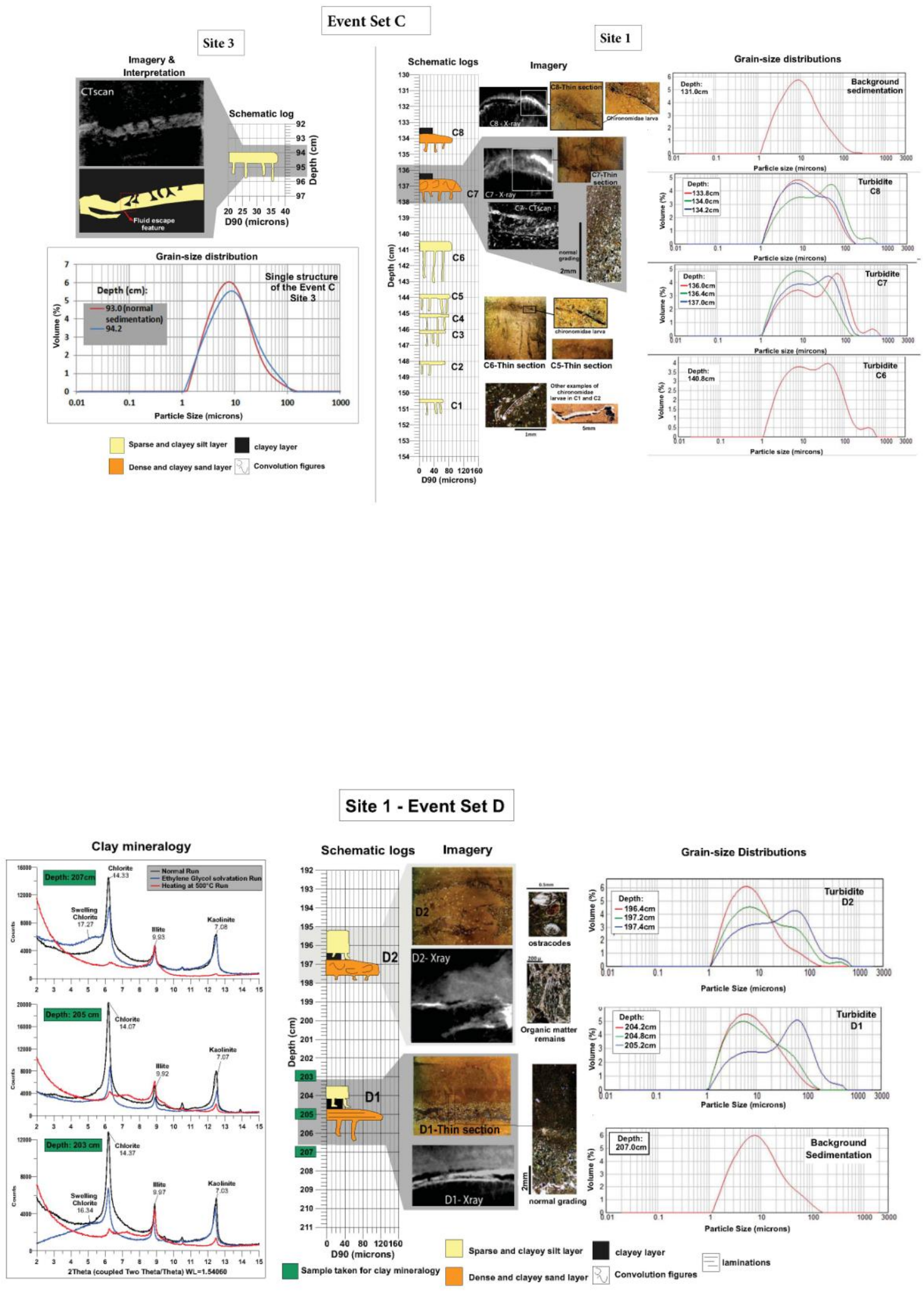

This article is protected by copyright. All rights reserved. 


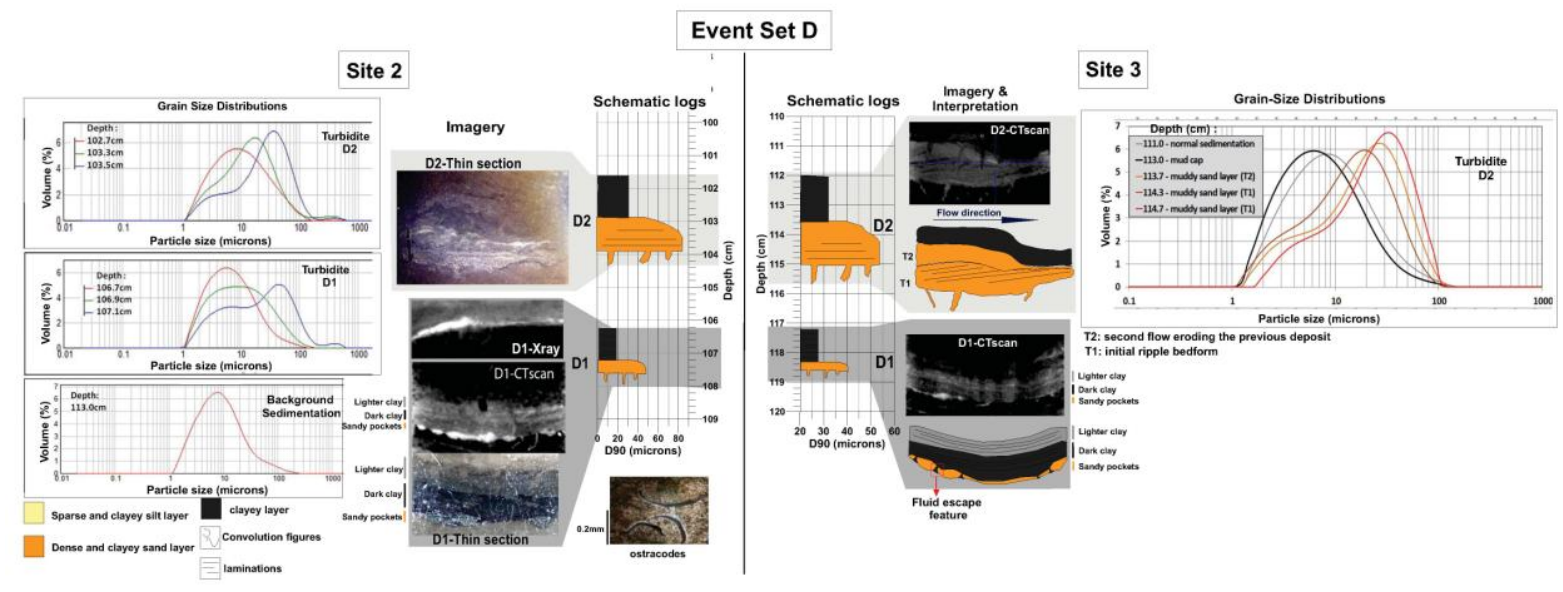

This article is protected by copyright. All rights reserved. 


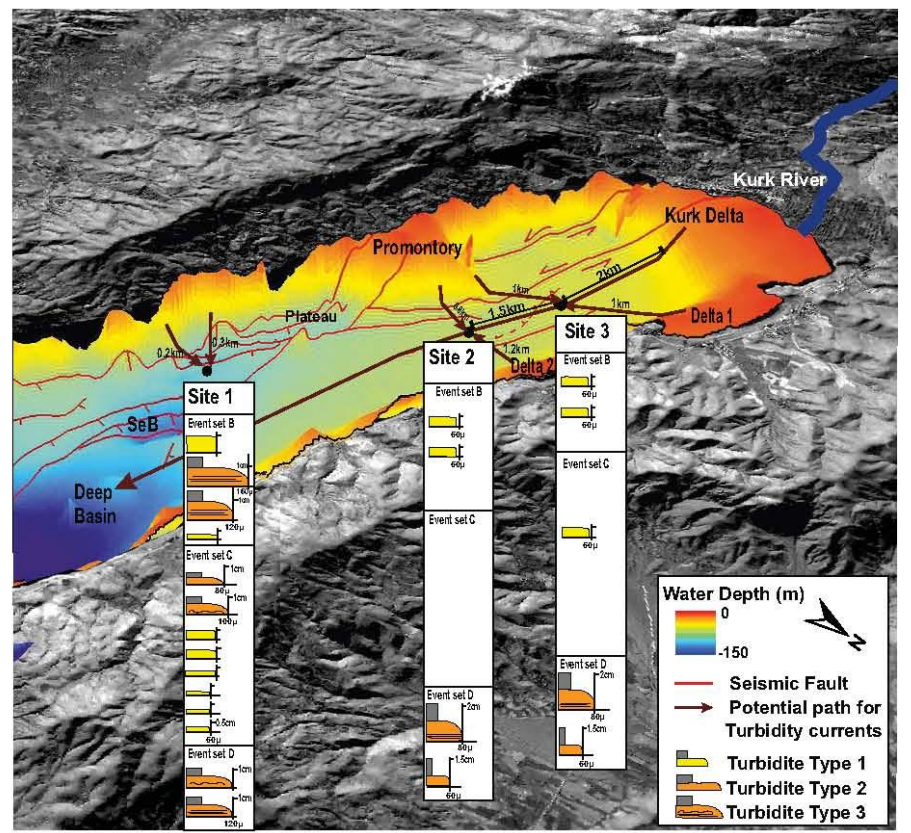

This article is protected by copyright. All rights reserved. 